\title{
The politics of numbers and additionality governing the national Payment for Forest Environmental Services scheme in Vietnam: A case study from Son La province
}

\author{
Pham Thu Thuy ${ }^{1}$, Ngo Ha Chau ${ }^{1}$, Dao Thi Linh $\mathrm{Chi}^{1}$, Hoang Tuan Long ${ }^{1}$, Micah R. Fisher ${ }^{2,3,4}$ \\ 1 The Center for International Forestry Research (CIFOR) \\ 2 Disaster Management and Humanitarian Assistance Program, University of Hawai'i at Mānoa \\ 3 Forestry Faculty of Universitas Hasanuddin, Makassar, Indonesia \\ 4 The Dala Institute \\ * Correspondence author: T.Pham@cgiar.org
}

\begin{abstract}
Payments for forest environmental services (PFES) is a major breakthrough policy in the Vietnamese forestry sector because it contributes $25 \%$ of the total investments in the forestry sector and serves as the first market-based instrument employed to protect forests. However, there is little empirical evidence of its effectiveness. Is the policy meeting the core objectives of improving forest cover and forest quality and is it also achieving its claims of supporting local livelihoods? This paper analyses the environmental, social, and economic impacts of PFES in Son La province, the longest standing implementation of a PFES scheme in Vietnam. Our study uses a sampling method that incorporates prematching and a before-after-control-intervention approach. Data was collected from government statistics, remote sensing analysis, focus group discussions involving 236 people, surveys with a total of 240 households, and key informant interviews with 45 people. Our findings show that additionality of PFES in Son La is controversial and depends on who collects the data and what data is used to evaluate the impacts of PFES. Data collection is also politicized to serve central, provincial and district government interests. Evidence shows that PFES has provided little additional income to individual villagers to protect forests in Son La. However, total PFES revenue paid to communities generates significant income for village communities. Moreover, not all villagers can receive continuous payments from PFES, meaning that PFES has not become a stable source of income, rendering the permanence of PFES limited. Improving monitoring and evaluation policies coupled with transparent, inclusive, independent mechanisms are essential to providing a more accurate reflection of impacts from PFES in Vietnam.
\end{abstract}

Keywords: Payment for forest environmental services; Vietnam; impact assessment; Son La

\section{Introduction}

Payment for forest environmental services (PFES) is one of the major forestry policies in Vietnam as it contributes $25 \%$ of the total annual investment in the forestry sector since 2008 (Pham et al., 2018). PFES aims to enhance forest cover and forest quality, improve local livelihoods and reduce state investment in the forestry sector (Pham et al., 2018). The public pays environmental services fees through water and electricity bills to hydropower plants and water supply companies. These intermediaries then transfer the payment to the Forest Protection and Development Fund, which acts as a government intermediary for paying and monitoring forest owners to protect forests. Although PFES implementation began in earnest in Vietnam since 2008, there are only a few rigorous assessments of PFES impacts on people's lives (e.g. Duong \& de Groot, 2018; Duong \& de Groot, 2020; Pham et al., 2015; Trædal \& Vedeld, 2017; Wichelns et al., 2016; Tran et al., 2016) and furthermore, there is limited empirical evidence on forest quality outcomes. More broadly, payment for environmental services (PFES) schemes, including the PFES in Vietnam, is only shown to be effective if there is well-evidenced additionality, such as improved forest conservation effects and improved local livelihoods compared with the predefined baselines (Mohebalian \& Aguilar, 2016; Wunder, 2007). This paper aims to address the knowledge gaps on PFES by using Son La province as 
an empirical case study by examining the impacts of PFES on the livelihoods of local people and forest protection. Document No. 129, issued in 2017 by the Ministry of Agriculture and Rural Development (MARD) and Vietnam Forest Protection and Development Fund, provides guidelines on monitoring and evaluation protocols, as well as corresponding assessment criteria for PFES in Vietnam. These assessment criteria are grouped into three themes: environmental (forest cover), social, and economic impacts of PFES. This paper follows the government monitoring and evaluation framework by asking three key questions: i) Has PFES led to increased forest cover and reduce deforestation? ii) Has PFES led to increased household income? and iii) Has PFES led to improvements in social conditions in Son La? For each question we examine the ways in which changes have occurred.

Evaluating PFES impact requires going beyond monitoring indicators by also understanding its additionality, namely: the difference between PFES environmental outcomes compared with the baseline in the absence of PFES, which also takes into account anticipated changes in external factors during the period when PFES were established, and elements that may affect Environmental Service provider activities (Angelsen, 2017; Le Velly \& Dutilly, 2016; Naeem et al., 2015; Wunder, 2005;). In this paper, we not only analyze PFES impact against government frameworks but also analyze the additionality of PFES compared with a business as usual scenario. Furthermore, although accurate understanding of PFES impact also depends on the availability and accuracy of data, data is also influenced by the interests of powerful agents (Brockhaus and Angelsen, 2012; De Sy et al., 2018). PFES monitoring systems are generally seen as a technical matter, while what is measured, reported, and verified, how and by whom, are politically driven (Gupta et al., 2012; Gupta et al., 2014). Therefore, rather than accepting available data on PFES impact at face value, this paper also adopts a political lens to analyze the politics of numbers related to PFES. We do this by extending research questions to incorporate dimensions of who analyzes the data, how the data is collected, and which interests are being served.

Son La was selected as the case study site to assess PFES impact in Vietnam for several reasons. First, the impact of PFES on forest ecosystem services are more valid with longer-term temporal and longitudinal data (Gupta et al., 2012; Gupta et al., 2014; Hasan et al., 2019; Jebiwott, 2016; Wang et al., 2020). Son La, as one of the first two provinces to conduct PFES in Vietnam (from 2008 to the present), provides more than a 10-year timespan to evaluate PFES impact. Moreover, the complexity and cost of monitoring and evaluation depends greatly on the variety of forest environmental services, the number of forest owners, the complexity of forest management practices, as well as local economic, social and political conditions. Forests account for $65.4 \%$ of the total natural area of the province and are currently managed by 54,000 forest owners (Son La Forest Protection and Development Fund, 2018). Therefore, as one of the most diverse provinces across the abovementioned factors, Son La provides opportunities to account for many valuable lessons learned on the design of monitoring and evaluation systems, and presents a pathway for studying the broader impact of PFES in Vietnam and beyond. The paper is structured into five sections. After the Introduction, Section 2 describes the methods employed in our study. Section 3 presents findings relative to the research questions in distinct sub-sections for: environmental impact (Section 3.1), economic impact (Section 3.2), social impact (Section 3.3) and also presents results as a politics of numbers (section 3.4). The discussion section then contextualizes findings in the broader literature, followed by conclusions that highlight implications for PFES.

\section{Methods}

Data were collected between August 2016 to June 2018 and included a wide range of research methods. PFES impact depends particular attention on monitoring the unit of scale (Wunder, 2005; Engel, 2016). In our study, we assessed PFES impact at provincial, district, commune and village levels. The Government of Vietnam uses environmental indicators to assess PFES, including forest 
area, forest cover, forest loss, number of forest violation cases, combined with economic indicators including household income, and incorporating social indicators, including number of poor households that benefit from PFES and number of households that engage in PFES programs (Pham et al., 2015; Pham et al., 2018). We complement this Government data collection by compiling from across different data sources to analyze how indicators have changed over time, which further helps to evaluate PFES impact at different governing scales.

The primary data source collection was guided by four overall approaches, particularly with an eye towards analyzing the impact of PFES at provincial, district, and commune levels. First, government reports and statistical records on forest area, forest cover, forest loss, number of forest violations were collected and analyzed for Son La. Second, annual and biannual PFES reports beginning in $\mathbf{2 0 1 0}$ were collected from the Son La Forest Protection and Development Fund, which is the main government focal point implementing PFES in the province. In addition, annual reports from hydropower plants and water supply companies (Environmental Services users in Son La) were reviewed to document any impacts since the implementation of PFES in 2008, in terms of forest cover, forest areas under PFES scheme, number of beneficiaries, and water quality as proxy for monitoring PFES impact. Third, as government reports and statistics on environmental and socioeconomic indicators applied by MARD used to evaluate PFES are not all available for different periods, we also complemented our analysis by using Hansen data on forest cover loss and forest cover gain to develop a clearer understanding of PFES impact. Although Hansen data might not be the same with government data, the findings are consistent with the trend of forest cover gain and forest cover loss in the area over time. Fourth, from October 2016 to August 2017, we conducted semi-structured interviews with representatives of 21 departments and agencies in Son La province and 3 representatives were from service users. These interviews aimed to understand the institutional setting and context of PFES implementation in Son La, particularly under the various environmental, social, and economic impacts of PFES at provincial, district and commune levels. As PFES has been implemented across Son La and in all districts and communes, we analyzed impacts of PFES by comparing indicators of before and after PFES. PFES was piloted in Son La in 2008, but only in 2009 did PFES begin implementation across the entire province. Therefore, 2009 was chosen as a comparison point before and after PFES in Son La.

To understand PFES impact at the village level, we used the Before - After - Control Intervention method (BACl) developed by Sunderlin et al., (2016). BACl is considered a robust method of analysis to improve the accuracy of evaluations of impact at the village level (Bos, 2020). To determine the exact matching pairs, we carried out three steps. First, we reviewed government reports on socio-economic development and forest protection in Son La and the biannual and annual reports from the Son La Forest Protection and Development Funds since 2008 to the present and identified a list of possible matched sites. We chose control and intervention sites to ensure that they are the same in some key aspects such as ethnicity, economic status, deforestation pressures, market and road accessibility, social background, and that they are subject to the same influence such as drivers of historical land use, historical forest governance structure, land tenure, presence of external projects (except PFES initiatives). We then consulted with five provincial government agencies on these potential lists on how representative these sites were and whether the sites are accessible for a research team to work in the area. Secondary data review and consultation was further carried out with five provincial government agencies, a pool of 15 candidate interventions and 15 control villages were selected. These sites are located in Muong Sang, Chieng Khua and Dong Sang communes of Moc Chau district, which were selected to represent diverse socio-economic conditions in Son La (e.g. ethnic group, different forest owners and user groups, economic status and forest condition) and based on willingness to participate in the study of local villagers and local authorities (Figure 1). 


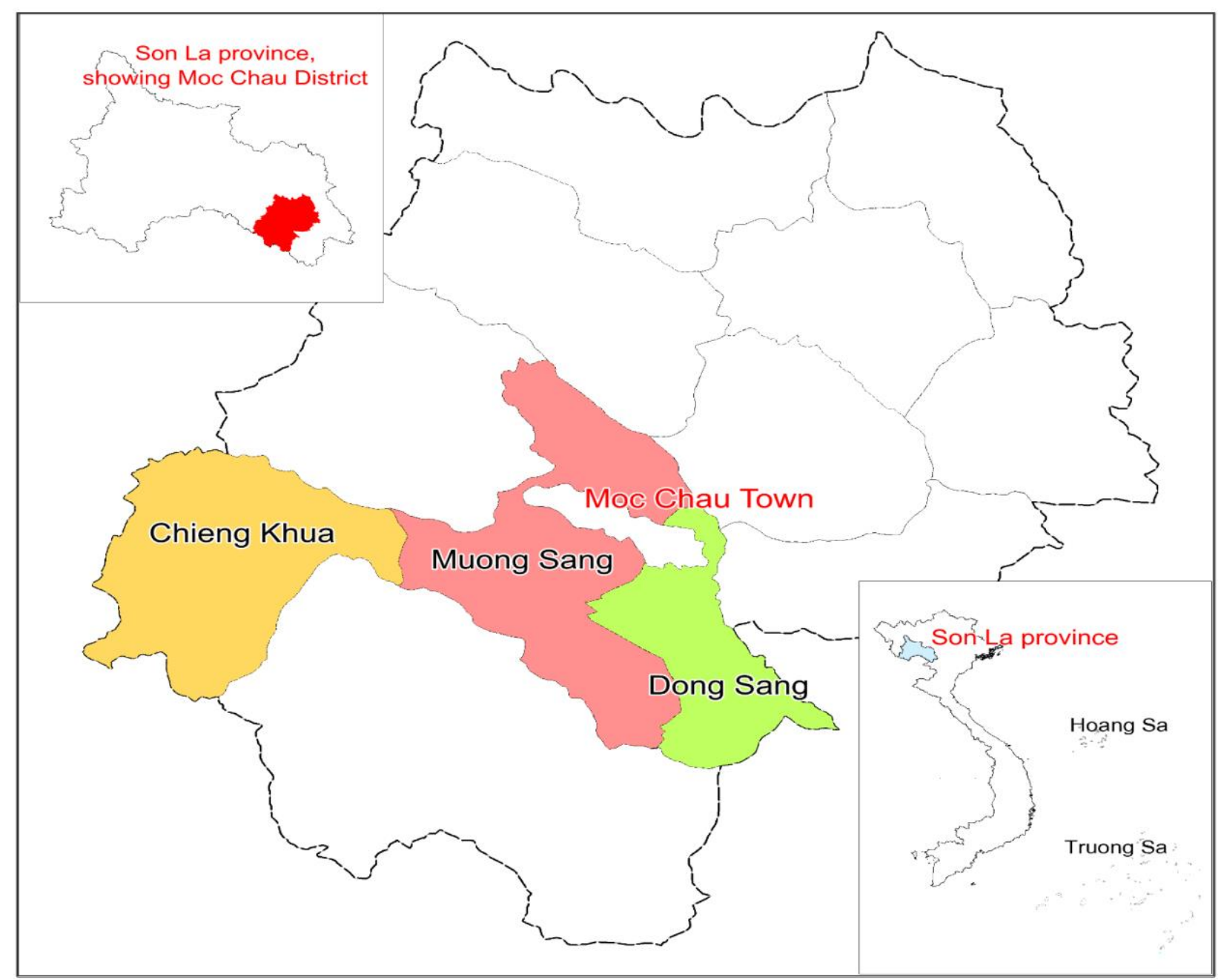

Figure 1. Studied sites

Table 1. Studied sties

\begin{tabular}{lcccccc}
\hline & $\begin{array}{c}\text { An Thái } \\
\text { Control }\end{array}$ & $\begin{array}{c}\text { Bản Trọng } \\
\text { Control }\end{array}$ & $\begin{array}{c}\text { Thái Hưng } \\
\text { Intervention }\end{array}$ & $\begin{array}{c}\text { Bản Lùn } \\
\text { Intervention }\end{array}$ & $\begin{array}{c}\text { Căng Ty. } \\
\text { Intervention }\end{array}$ & $\begin{array}{c}\text { Bản Phách } \\
\text { Intervention }\end{array}$ \\
\hline $\begin{array}{l}\text { Total } \\
\text { number of } \\
\text { household }\end{array}$ & 80 & 26 & 100 & 130 & 86 & 131 \\
\hline $\begin{array}{l}\text { Total forest } \\
\text { areas (ha) }\end{array}$ & 38.20 & 265.94 & 188 & 1477.243 & 270.736 & 564.396 \\
\hline $\begin{array}{l}\text { Number of } \\
\text { poor } \\
\text { households }\end{array}$ & 0 & 7 & 0 & 9 & 59 & 42 \\
\hline $\begin{array}{l}\text { Dominant } \\
\text { Ethnicity }\end{array}$ & Kinh & H'Mông & Kinh & Kinh, Thái & H'Mông & Kinh, Thái \\
\hline
\end{tabular}

We then conducted field visits to verify the sites and narrowed down the list of potential sites before identifying a sub-set of matched intervention and control villages that have similar characteristics. In reality, a matched control and intervention village cannot be completely similar in terms of its environmental, institutional, social and economic context, but we tried to match similar features as much as possible. Based on secondary data, consultation results and field visits, the research team chose two control sites and four intervention sites that reflect key influential criteria. Following Sunderlin et al.,'s (2016) approach to select four intervention sites and four 
control sites, we further modified the approach because there were only two sites that could function as control sites in the study area, as all other villages were already engaged in PFES. As a result, we only have two control sites and four intervention villages (Table 1).

In each village, focus group discussions were conducted with men and women groups (Table 2). These discussions focused on the drivers of deforestation and degradation, local socio-economic conditions where PFES is implemented, impacts of PFES on forests and local livelihood, with particular emphasis on exploring the strengths and weaknesses of PFES.

Table 2. Number of participants in the in-depth group discussion

\begin{tabular}{|c|c|c|}
\hline Village & Men & Women \\
\hline Bản Lùn & 12 & 12 \\
\hline Thái Hưng & 13 & 13 \\
\hline An Thái & 10 & 12 \\
\hline Bản Phách & 12 & 12 \\
\hline Bản Trọng & 12 & 12 \\
\hline Căng Ty. & 12 & 12 \\
\hline Total & 71 & 73 \\
\hline
\end{tabular}

Household surveys were also conducted in six villages covering a total of 240 households (Table 3). These household surveys aimed to understand the nature of households characteristics, such as number of family members, ethnicity, and educational background, engagement in PFES (length of contract, participation in PFES or not) and household perceptions on changes before and after PFES in terms of forest resources, access to the forest, household income, and participation in forest conservation schemes.

We also collected and reviewed data on PFES contracts, PFES payment and PFES areas at the intervention sites, which we obtained from the Son La Forest Protection Fund, as well as the commune people's committee reports on forest status, forest protection programs implementation and policies, as well as socio-economic development in both intervention and control villages. This data was used to analyze any potential impacts that can be attributed to PFES.

Table 3. Number of households surveyed in 6 villages

\begin{tabular}{lcccccc}
\hline & $\begin{array}{c}\text { An } \\
\text { ThaiControl }\end{array}$ & $\begin{array}{c}\text { Bang } \\
\text { Trong } \\
\text { Control }\end{array}$ & $\begin{array}{c}\text { Thai Hung } \\
\text { Intervention }\end{array}$ & $\begin{array}{c}\text { Ban } \\
\text { Lunlntervention }\end{array}$ & $\begin{array}{c}\text { Cang Ty } \\
\text { Intervention }\end{array}$ & $\begin{array}{c}\text { Ban Phach } \\
\text { Intervention }\end{array}$ \\
\hline $\begin{array}{l}\text { Number of } \\
\text { households in } \\
\text { the village }\end{array}$ & 80 & 26 & 100 & 130 & 86 & 131 \\
\hline $\begin{array}{l}\text { Number of } \\
\text { households } \\
\text { interviewed }\end{array}$ & 30 & 26 & 26 & 30 & 64 & 60 \\
\hline
\end{tabular}

\section{Findings}

\subsection{Environmental impact}

To assess the environmental impacts of Son La, indicators used by government officers included: changes in forest areas and forest loss at the provincial, district, commune and village level, such as considerations of deforestation and forest fire conditions. In this paper, we present findings on changes in forest areas at the provincial level in section 3.1.1., scaling to the district level in section 3.1.2, then to the commune level in section 3.1.3 and finally the village level in section 3.1.4. 


\subsubsection{Changes in Forest areas at the provincial level}

The additionality of PFES in enhancing forest area in Son La at the provincial level can be seen differently depending on what data is used. Hansen data on annual loss of forest cover in Son La from 2001 - 2019 shows limited additionality of PFES in reverting forest cover loss trends as there is no change before and after PFES. The annual loss of forest cover since 2009 when PFES began increased sharply before dropping again in 2012 and has gradually began to increase again since then (Figure 2). According to government agencies interviewed, this sharp increase in annual forest cover loss is mainly due to the expansion of hydropower plants and maize production.

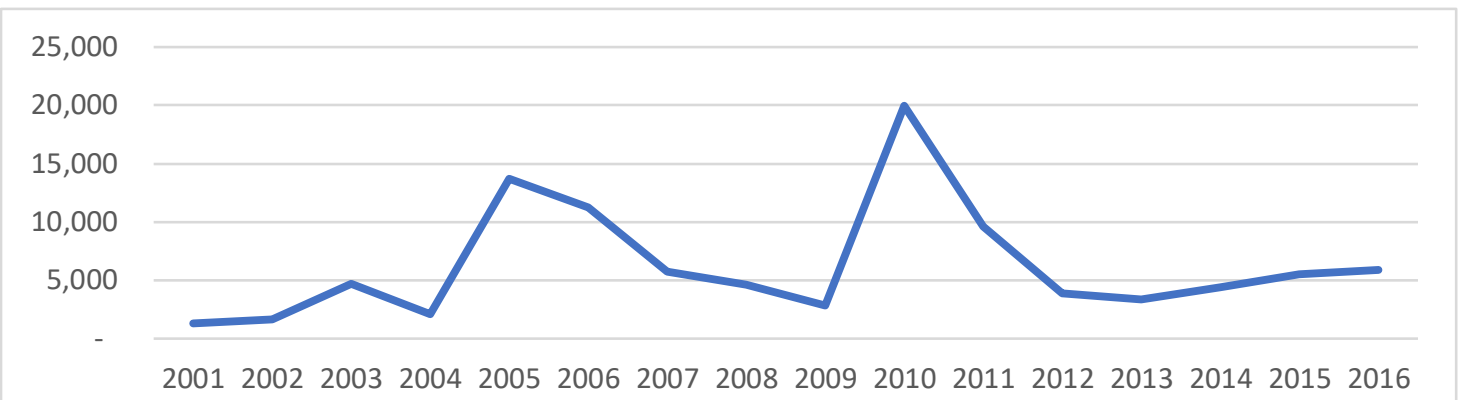

Figure 2. Annual forest cover loss in Son La 2001- 2016. Source: Hansen et al. (2016)

Table 4 further confirms that although before the PFES period total forest cover loss was only 45,037.8 ha between 2001-2008, since PFES began implementation in 2009, total forest cover loss increased from $45,037.8$ to $55,474.5$ ha.

Table 4. Annual provincial forest cover loss and total forest cover loss between 2001 - 2016

\begin{tabular}{cccc}
\hline $\begin{array}{c}\text { Annual Forest cover loss } \\
\text { (ha/y) }\end{array}$ & $\begin{array}{c}\text { Total forest cover loss } \\
\text { (ha) }\end{array}$ & $\begin{array}{c}\text { Annual Forest cover } \\
\text { loss }\end{array}$ & $\begin{array}{c}\text { Total forest cover loss } \\
\text { (ha) }\end{array}$ \\
\hline $\mathbf{2 0 0 1 - 2 0 0 8}$ & $2001-2008$ & $2009-2016$ & $2009-2016$ \\
\hline $\mathbf{5 , 6 2 9 . 7}$ & $45,037.8$ & $6,934.3$ & $55,474.5$ \\
\hline
\end{tabular}

Source: Hansen et al. 2016

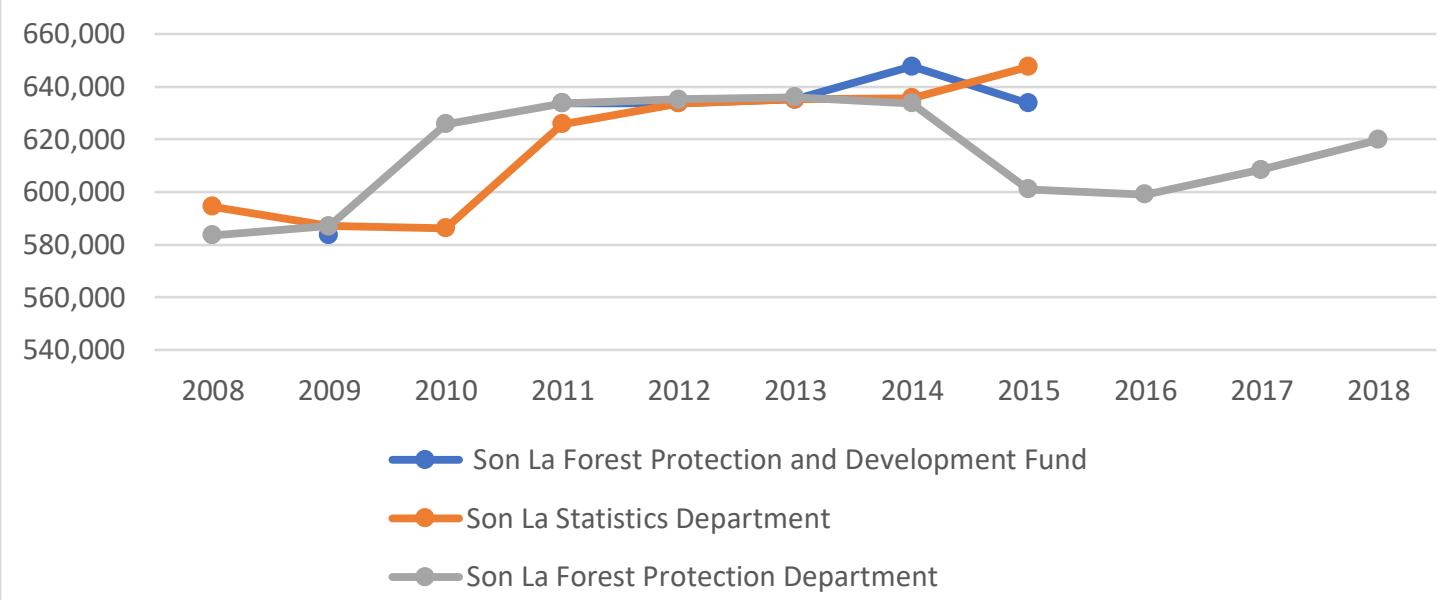

Figure 3. Forest area in Son La Province from 2008-2018 (ha). Sources: Son La Forest Protection and Development Fund (2018); Son La Forest Protection Department (2018); Son La Statistics Department (2018). 
In contrast, data collected and published by different government agencies show PFES additionality by presenting figures on increased forest cover, reduction in the number of deforestation cases, and declining area of cleared forests. Figure 3 presents government data on forest areas in Son La and these datasets show PFES additionality increasing forest area at the provincial level at a range of 20,000 ha of forests to 70,000 ha of forests, depending on which government agency data are used.

Moreover, according to provincial statistics, PFES additionality is well-demonstrated by the government through the number of deforestation cases and deforestation areas fluctuating over time, and which gradually decreased (Figure 4). Before PFES, the number of cases in Son La in 2008 was 1,000 but dropped to less than 50 cases in 2015. Most government staff interviewed claimed that this might partly be because of PFES but could also be attributed to the government implementing multiple forest protection and poverty reduction programs in the province, thus posing difficulty in pinpointing the specific additionality of PFES.

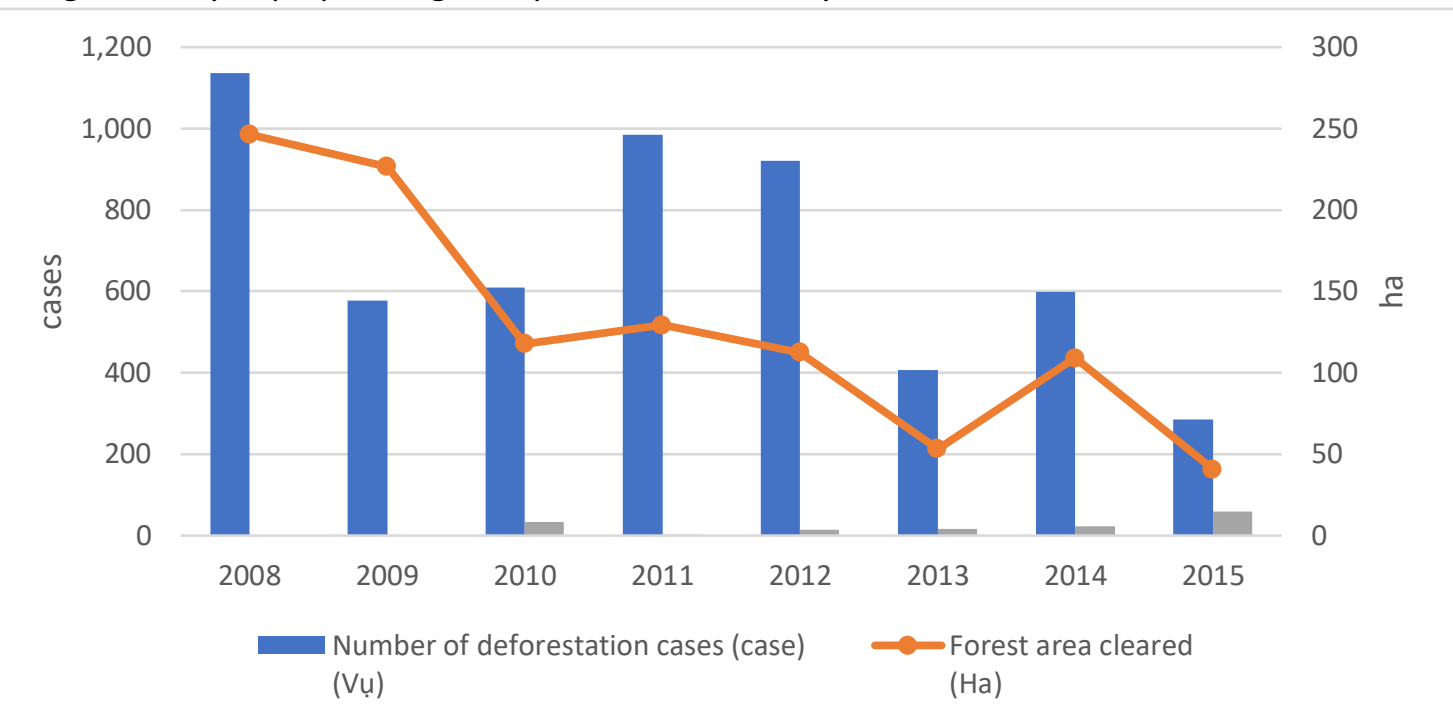

Figure 4. Deforestation in Son La province over the years. Source: Son La Forest Protection and Development Fund 2018

However, data published by government agencies (Figure 5) also indicates limited additionality of PFES in reducing forest loss and cases of forest fire, as both the documented area of forest loss and incidence of forest fire cases gradually increased over time.

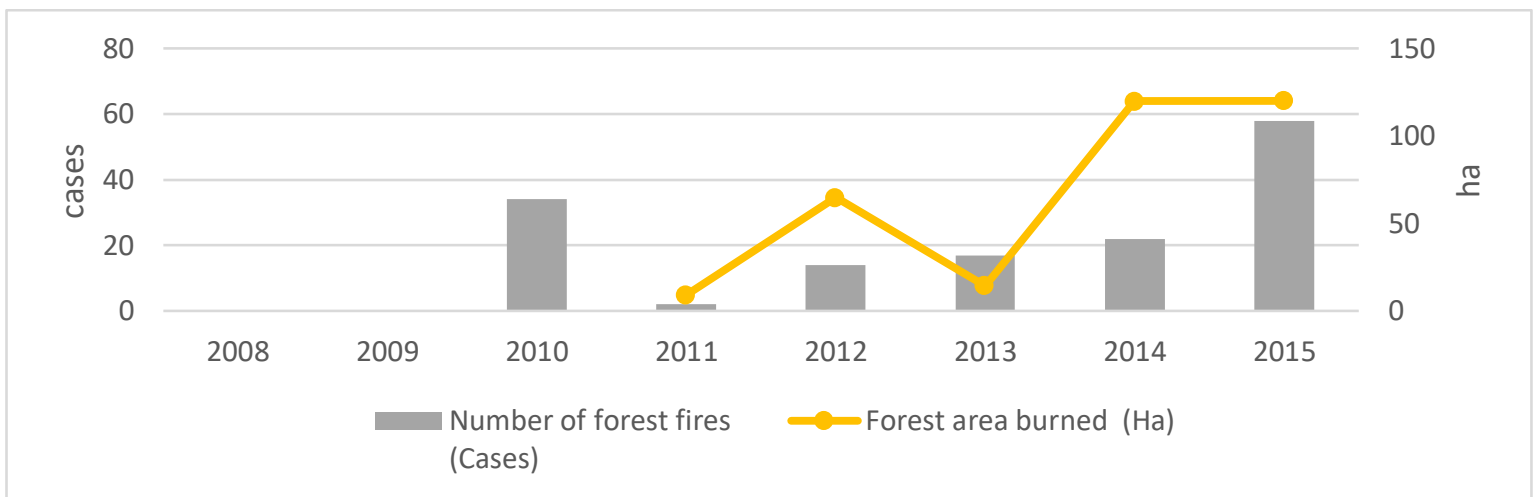

Figure 5. Number of forest fire cases and forest area loss due to fire over years $2010-2015$. Source: Son La Forest Protection and Development Fund 2018 
According to an interview with staff at the Son La Forest Protection and Development Fund, these increases in forest loss were due to fires, which is also mainly attributed to the naturally dry weather during that period. However, interviews with other government agencies also revealed other causes for the increasing number of fires, such as due to expanding agricultural production encroaching into forests.

Although PFES implementation in Son La began since 2008, the actual land allocation process to define the forest boundary took a long time, which resulted in actual payments beginning only in 2011. Data published by the Son La Forest Protection and Development Fund also shows that despite an increase in forest areas under PFES schemes in Son La increasing between 2011- 2015, forest areas also fell slightly from 2016 - 2018 (Figure 6).

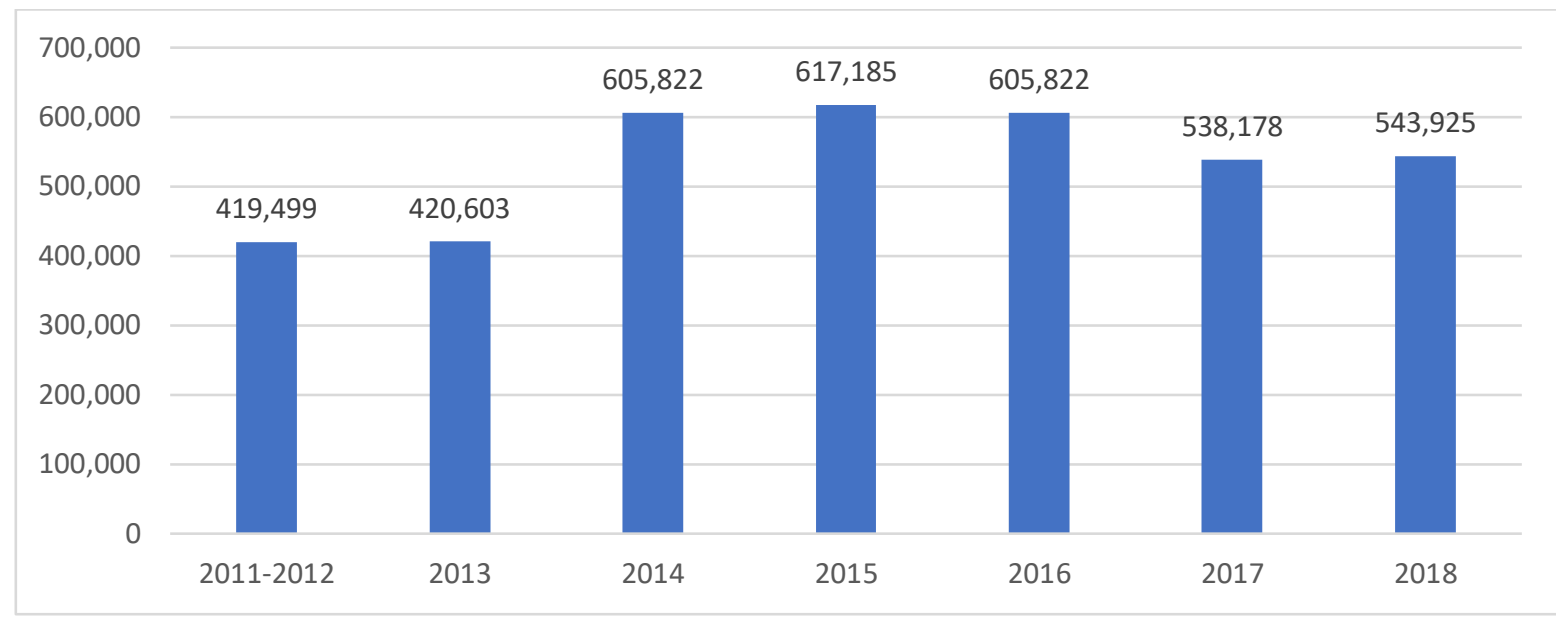

Figure 6. Forest area paid under PFES scheme (2011-2018) (Unit: ha). Source: Son La Forest Protection and Development Fund 2018

The decrease in PFES area as explained by the Son La Forest Protection and Development Fund was due to changes in forest definitions resulting in some areas not being eligible to receive PFES. This is also consistent with Figure 2 which also shows that the overall forest area in Son La province increased between 2008 to 2013 but slightly declined in 2014 - 2015 (Son La Forest Protection and Development Fund 2018; Son La Statistics Department 2018). This decrease in forest area is mainly due to the change on national forest definitions, which took place in 2013. Before 2013, forests were defined as $10 \%$ of tree cover. However, Decision No. 689/QĐ-TCLN-KL dated 23/12/2013 issued by VNFOREST regulated that not only do forests needs to have $10 \%$ tree cover, but timber volume also needs to be above $10 \mathrm{~m}^{3}$, which led to a large area of newly regenerated forests not fulfilling this criterion. Moreover, according to interviewees with the Son La Forest Protection and Development Fund and the Son La Forest Protection Department, previous monitoring techniques were manually conducted, and results were inaccurate. The current measurement method is supported by highresolution satellite imagery in combination with on-the-ground surveys to identify and assess forest area, quality, and volume, thus increasing the overall accuracy and eliminating areas without forests.

\subsubsection{Changes in Forest areas at the District Level}

Similar to findings at the provincial level, the additionality of PFES at the district level also varied depending on what data was used to make the assessment. Hansen data shows that after PFES was implemented in Moc Chau district, annual forest loss slightly declined between 2010-2014 before increasing again since 2014 (Figure 7). 


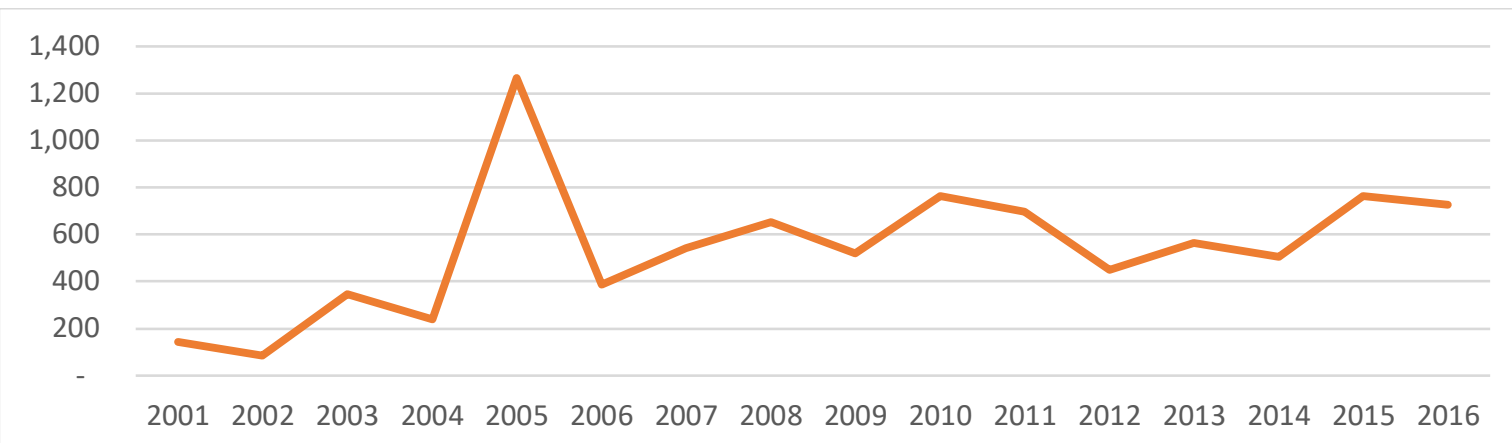

Figure 7. Annual loss of forest cover in Moc Chau district 2001- 2016 (ha). Source: Hansen data (2016)

Table 5 also shows that PFES has limited additionality and impact in Moc Chau district because total forest cover loss increased from 3,661.8 ha between 2001- 2008 (before PFES started in Moc Chau) to 4,991.8 ha after PFES (between 2009- 2016).

Table 5. Moc Chau annual forest cover loss and total forest cover loss 2001- 2016

\begin{tabular}{cccc}
\hline $\begin{array}{c}\text { Annual Forest cover loss } \\
\text { (ha/y) }\end{array}$ & $\begin{array}{c}\text { Total forest cover } \\
\text { loss (ha) }\end{array}$ & $\begin{array}{c}\text { Annual Forest } \\
\text { cover loss }\end{array}$ & $\begin{array}{c}\text { Total forest cover } \\
\text { loss (ha) }\end{array}$ \\
\hline $\mathbf{2 0 0 1 - 2 0 0 8}$ & $2001-2008$ & $2009-2016$ & $2009-2016$ \\
\hline $\mathbf{4 5 7 . 7}$ & $3,661.8$ & 624.0 & $4,991.8$
\end{tabular}

Source: Hansen et al. 2016

The Hansen data is also consistent with data published by the Son La government statistics department, which indicated that forest areas in Moc Chau increased only slightly from 2010 to 2012 followed by a sharp decline from 2012 to 2015 (Figure 8). Meanwhile, the Son La Forest Protection and Development Fund argues that this reduction is due to changes in forest conditions and monitoring techniques. Some provincial authorities admitted that this decrease is due to forest conversion from the expansion of fruit tree plantations in recent years.

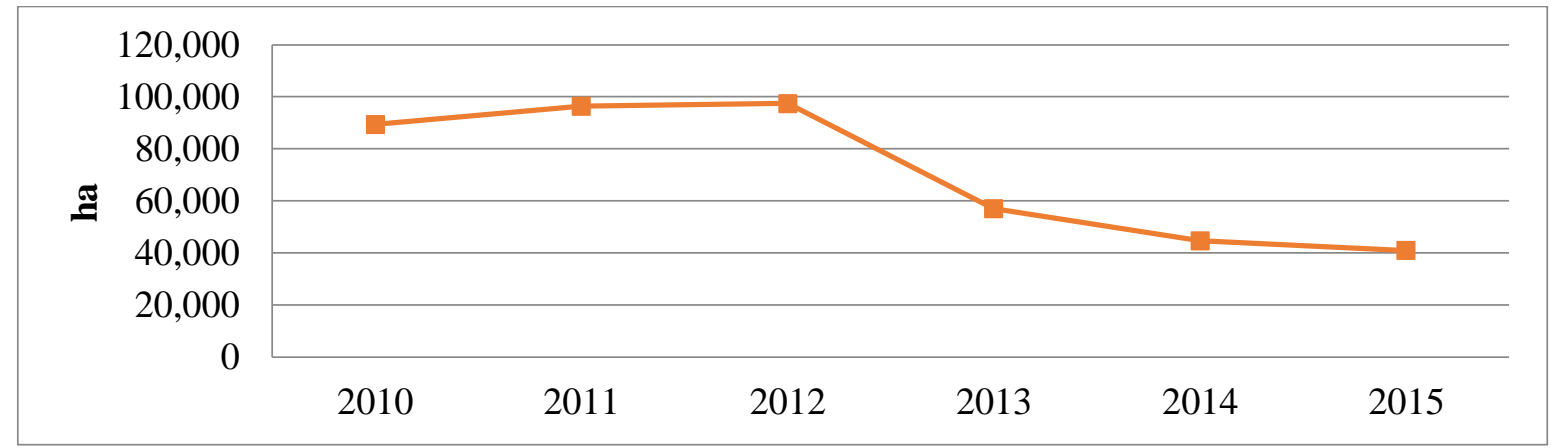

Figure 8. Forest area in Moc Chau district 2010-2015. Source: Son La Statistic Department 2016

\subsubsection{Changes in forest areas at the Commune level}

There is no publicly available data from government agencies on forest areas in the communes of Muong Sang, Dong Sang and Chieng Khua. Therefore, our assessment at the commune level was mainly based on accessing the Hansen data. Figure 9 shows presents the data, and given that PFES began in Son La in 2009, the three studied communes indicate gradual overall reductions in annual forest cover loss. 


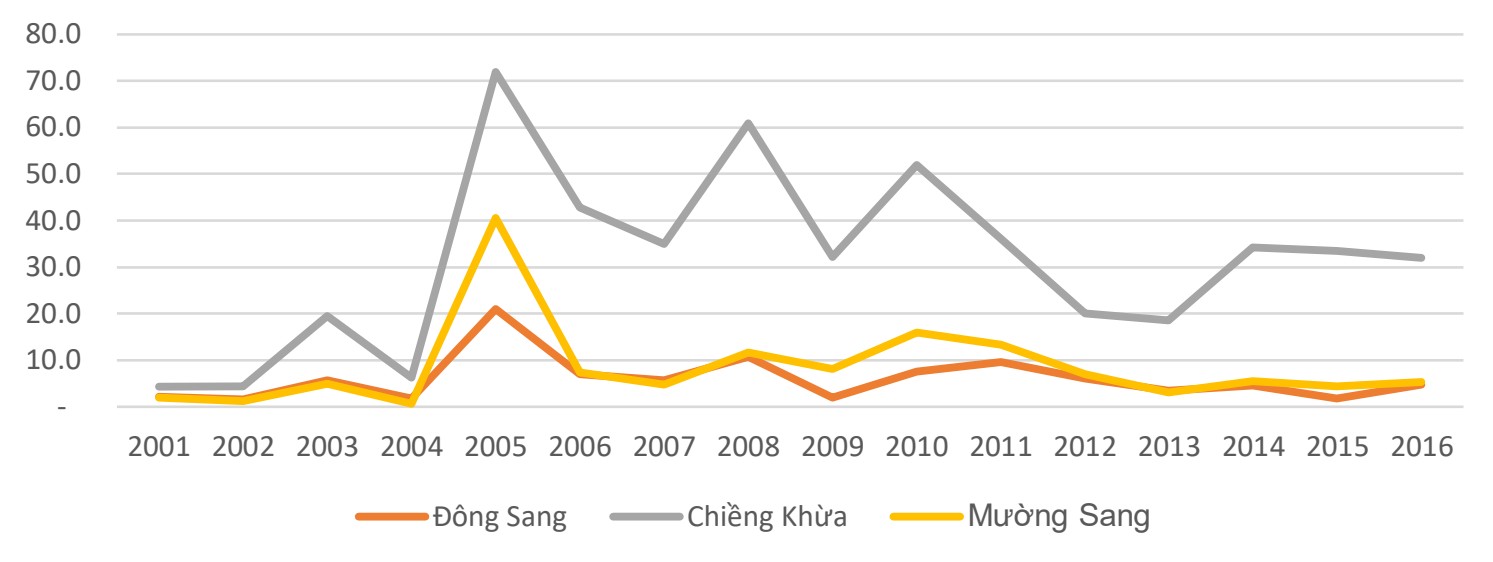

Figure 9. Annual forest cover loss in Đông Sang, Chiềng Khừa and Mường Sang communes

Table 6 shows that before PFES (years 2001 - 2008), the annual forest cover loss in Muong Sang commune was 9.1 ha/year, but since PFES was introduced, losses declined to 7.8ha/year. Similarly, in Dong Sang commune, before PFES (2001 - 2008), the annual forest cover loss was 6.9 ha/year but declined to 4.9 ha/year after PFES implementation in 2009. In contrast, Chieng Khua commune annual forest cover loss increased slightly, from 30.6 ha/year before PFES (2001 - 2008) to 32.3ha/year after PFES began in Son La.

According to interviews with Dong Sang and Muong San commune government officers, annual forest lost decreased in these two communes because government programs such as PFES provided financial support for communities to protect forests. They also shared another important factor, namely the arrival of access to electricity. This has had an influence in transitioning away from firewood as the main source of energy for cooking sources. In contrast, Chieng Khua commune has promoted the goal of expanding agriculture and fruit gardens as part of their poverty reduction strategy (Dung Minh, 2018). Illegal logging and high rates of deforestation in Chieng Khua commune has also been widely reported in the mass media (Mùi Sơn \& Minh Hải, 2019; Vietnam Administration of Forestry, 2013; Son Ha, 2019).

Table 2. Annual forest loss at commune levels between $2001-2016$

\begin{tabular}{lcccc}
\hline & $\begin{array}{c}\text { Annual Forest } \\
\text { cover loss }(\mathrm{ha} / \mathrm{y})\end{array}$ & $\begin{array}{c}\text { Total forest } \\
\text { cover loss (ha) }\end{array}$ & $\begin{array}{c}\text { Annual Forest } \\
\text { cover loss (ha/y) }\end{array}$ & $\begin{array}{c}\text { Total forest } \\
\text { cover loss (ha) }\end{array}$ \\
\cline { 2 - 5 } & $\mathbf{2 0 0 1 - 2 0 0 8}$ & $\mathbf{2 0 0 1 - 2 0 0 8}$ & $\mathbf{2 0 0 9 - 2 0 1 6}$ & $\mathbf{2 0 0 9 - 2 0 1 6}$ \\
\hline Mường Sang & 9.1 & 73.2 & 7.8 & 62.6 \\
\hline Chiềng Khừa & 30.6 & 245.0 & 32.3 & 258.4 \\
\hline Đông Sang & 6.9 & 55.5 & 4.9 & 39.5 \\
\hline
\end{tabular}

Source: Hansen et al. (2016)

\subsubsection{Changes in forest areas at the village level}

Changes in forest areas at control and intervention sites are assessed by analyzing available and published data and are also based on household perceptions from interviews inquiring into changes in forest areas before and after PFES. Hansen data is not available at the village level and there is no available and published data from government agencies on forest area at the control sites. According to interviews with forest rangers and provincial government staff, data on forest cover at the village level are not regularly collected by government, and if collected, results are recorded mostly based on forest ranger estimates rather than through an actual inventory. According to Commune leaders interviewed, in all villages studied there are no systematic reports or records on 
annual forest area. The lack of systematic data means that additionality of PFES is more difficult to ascertain.

Data availability at intervention sites on forest area are only collected and published by the Forest Protection and Development Fund, which commenced after PFES programming began. According to interviewed staff, data on forest area in these villages are only available because the Fund needs to monitor forest area over time to justify payments to households. In this regard, the contribution of PFES not only creates financial incentives for forest managers to protect forests, but also helps to improve forest monitoring and evaluation, as well as enhancing data transparency in Son La.

Data availability on forest area under PFES schemes in the four intervention villages from 2009 to 2018 were obtained from the 180 household interviews at the intervention sites. A household can benefit from PFES in two ways. First, they can sign a PFES contract with the Son La Forest Protection Fund as an individual consultant if they have a certificate for forest land use. Second, a community can sign a PFES contract with the Son La Forest Protection and Development Fund as a community member and these households can take part in and benefit from PFES. In our study, 73 out of the 180 households received PFES payments as individual households, and 107 households received PFES payments directed at community forest protection (Table 7).

Table 7. PFES payments to individual households and community members at the 4 intervention sites

\begin{tabular}{|c|c|c|c|c|c|}
\hline & Total & Ban Lun & Thai Hưng & Phach & Cang Ty \\
\hline $\begin{array}{l}\text { No. of } \mathrm{HH} \text { receiving direct } \\
\text { PFES payments to individual } \\
\text { households }\end{array}$ & 73 & 23 & 13 & 33 & 4 \\
\hline $\begin{array}{l}\text { No. of } \mathrm{HH} \text { receiving PFES } \\
\text { payments through joining } \\
\text { community forest } \\
\text { protection and management } \\
\text { programs }\end{array}$ & 107 & 37 & 17 & 27 & 26 \\
\hline
\end{tabular}

Source: Analysis from household surveys

The published data available on forest area in PFES villages for both community forests and individual forests show that the PFES forest area in the 4 intervention villages fluctuated over time. Cang Ty and Thai Hung have less fluctuation compared to Phach and Ban Lun villages (Figure 10). There is a slight increase in the forest area in Thai Hung and Cang Ty villages overtime since PFES began in 2009. Ban Lun and Ban Phach also witnessed a sharp increase in forest cover after PFES was initiated but then experienced a sharp decline after 2013. This shows that PFES has had a minimal effect in increasing forest cover in Thai Hung and Cang Ty, while it has had no effect in preventing forest loss in Ban Lun and Ban Phach.

Amongst the 73 individual households who obtain payments by PFES for their individual forests, data from the Son La Forest Protection and Development Fund (Table 8) show that most forest areas receiving payments by PFES declined or fluctuated overtime. This shows not only the unstable impacts of PFES but also the little additionality and effect of PFES schemes at the individual household level. 


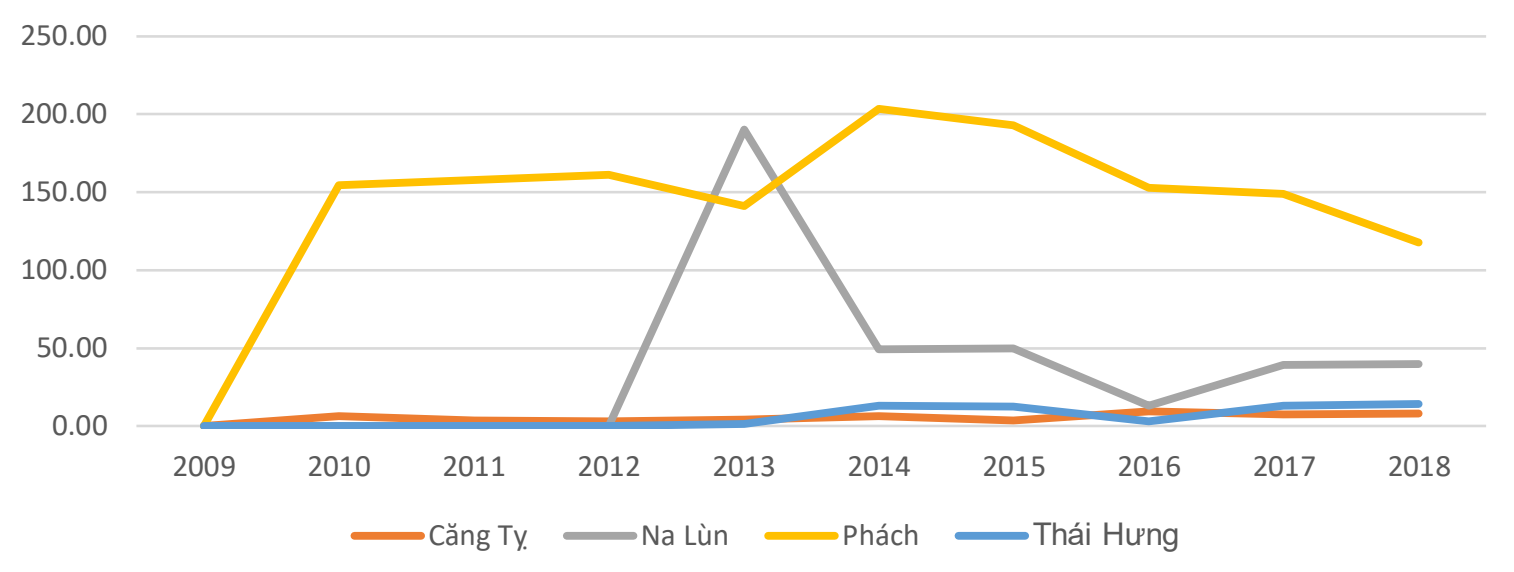

Figure 10. Forest areas that in 4 intervention villages between 2009- 2018 (Unit: ha). Source: Son La Forest Protection and Development Fund 2018

Table 8. Local perceptions on changes in PFES area comparisons between $2009-2018$ in four intervention sites

\begin{tabular}{lccccc}
\hline & Total & $\begin{array}{c}\text { Ban } \\
\text { Lun }\end{array}$ & $\begin{array}{c}\text { Thai } \\
\text { Hưng }\end{array}$ & Phach & $\begin{array}{c}\text { Cang } \\
\text { Ty }\end{array}$ \\
\hline $\begin{array}{l}\text { Total number of HH receiving PFES } \\
\text { payments as an individual }\end{array}$ & 73 & 23 & 13 & 33 & 4 \\
\hline $\begin{array}{l}\text { Number of HH receiving PFES for only 1 year in } \\
2018\end{array}$ & 6 & 3 & 2 & 0 & 1 \\
\hline $\begin{array}{l}\text { Number of HH that have forest areas paid by } \\
\text { PFES increasing over time }\end{array}$ & 10 & 3 & 1 & 5 & 1 \\
\hline $\begin{array}{l}\text { Number of HH that have forest areas paid by } \\
\text { PFES decreasing over time }\end{array}$ & 20 & 5 & 3 & 10 & 2 \\
\hline $\begin{array}{l}\text { Number of HH that have forest areas paid by } \\
\text { PFES remains the same over time }\end{array}$ & 4 & 1 & 1 & 2 & 0 \\
\hline $\begin{array}{l}\text { Number of HH that have forest areas paid by } \\
\text { PFES fluctuating overtime: Increased in some } \\
\text { years and decreased in other years }\end{array}$ & 33 & 11 & 6 & 16 & 0 \\
\hline
\end{tabular}

Source: Analysis from household survey

Table 9. Local perceptions on forest clearing between before and after PFES (Unit: percentage of household interviewed)

\begin{tabular}{lcc}
\hline & Intervention sites & Control sites \\
\hline $\begin{array}{l}\text { Have never cleared or stopped } \\
\text { clearing forests after PFES }\end{array}$ & 78.8 & 78.5 \\
\hline Clear more forest since PFES & 1.0 & 0 \\
\hline $\begin{array}{l}\text { Clear forests at the same rate before } \\
\text { and after PFES }\end{array}$ & 1.6 & 0 \\
\hline $\begin{array}{l}\text { Clear less forests after PFES is } \\
\text { implemented }\end{array}$ & 4.3 & 0 \\
\hline Unanswered & 14.1 & 21.4 \\
\hline
\end{tabular}

Source: Analysis from household's survey

When comparing household perceptions on changes in terms of forest area before and after PFES, survey results show differences in forest area change between control and intervention sites. 
In all PFES villages, $88 \%$ of total villagers interviewed claimed that forest area remained the same before and after PFES, while $98 \%$ of total villagers interviewed at the control site felt this way. When comparing forest quality before and after PFES, 59\% of total households surveyed at intervention sites perceived improved forest quality, while only $30 \%$ of total households surveyed in control sites were of the same mind. Table 9 thus shows that PFES has had little additionality in reducing forest clearing as only $4.3 \%$ of total households interviewed at intervention sites claimed that they have reduced forest clearing after PFES.

\subsection{Economic impacts}

The Government of Vietnam assesses PFES impact through the central issue of improving local income. Provincial and commune government agencies claimed that before PFES, both intervention and control sites only received payment for forest protection with payment levels at 50,000 VND/ha under the National Reforestation Program (Program 661). When Program 661 ended in 2010, household interviews in control sites indicated that they did not receive any payment for forest protection while households interviewed in intervention sites received PFES payments.

\subsubsection{Contribution of forestry and PFES to overall household income}

In all studied villages, regardless of whether at intervention or control sites, all villagers interviewed received income from forestry. However, the average income generated from forestry (including PFES) at the intervention sites are 2.31 times higher than in the control site (Table 10). In the villages without PFES, respondents indicated that the highest income households could obtain from forestry is VND 8 million, while the max figure is VND 10 million in villages with PFES. In both villages with PFES and without PFES, the average income from forestry accounts for a very small proportion compared to other sources, especially agriculture. Moreover, when compared before and after PFES, $76 \%$ of households interviewed in all four intervention villages and all households surveyed in control villages indicated there had been no change in income since PFES was instituted.

Table 10. Percent of interviewed households with different sources of income $(N=240)$ and the average income from different sources in 2017

\begin{tabular}{lcccc}
\hline Income source & \multicolumn{2}{c}{$\begin{array}{c}\text { Villages with PFES } \\
\text { (N= 180 households) }\end{array}$} & \multicolumn{2}{c}{$\begin{array}{c}\text { Villages without PFES } \\
\text { (N=56 households) }\end{array}$} \\
\cline { 2 - 5 } & \% total income & $\begin{array}{c}\text { Average } \\
\text { income } \\
\text { (Million VND) }\end{array}$ & \% total income & $\begin{array}{c}\text { Average income } \\
\text { (Million VND) }\end{array}$ \\
\hline Agriculture & 79 & 55.4 & 92.6 & 64.13 \\
\hline Forestry & 1.78 & 1.25 & 0.78 & 0.54 \\
\hline Business & 14.34 & 10.06 & 5.26 & 3.64 \\
\hline Salary & 3.29 & 2.31 & 0.65 & 0.45 \\
\hline Other & 1.59 & 1.15 & 0.71 & 0.38 \\
\hline Total & 100 & 70.17 & 100 & 69.14 \\
\hline
\end{tabular}

Source: Results from household survey

Survey respondents could not recall their exact income 10 years ago when PFES first began but all of them claimed that despite income differences between these time periods, the overall contribution of income from forestry remain unchanged before and after PFES.

Table 11 shows that total forestry revenues in both villages with PFES and without PFES come from multiple sources. However, revenue from firewood and timber is the main source of income for many households, while PFES contributes only a very small portion of overall income. Income from firewood is 4 times higher and income from bamboo and bamboo shoots is 7.34 times higher than income from PFES. As a result, those who received PFES payments indeed benefited from 
additional income from forestry, but they also indicated that the additional sum is not very significant.

Table 11. Annual income sources from forestry

\begin{tabular}{lcccc}
\hline & \multicolumn{2}{c}{ Village with PFES } & \multicolumn{2}{c}{ Village without PFES } \\
\cline { 2 - 5 } & $\begin{array}{c}\text { Households (\% } \\
\text { out of } 180 \\
\text { households) }\end{array}$ & $\begin{array}{c}\text { Average income } \\
\text { (VND million) }\end{array}$ & $\begin{array}{c}\text { Households (\% } \\
\text { out of 54 } \\
\text { households) }\end{array}$ & $\begin{array}{c}\text { Average income } \\
\text { (VND million) }\end{array}$ \\
\hline PFES & 33.6 & 0.95 & 0 & 0 \\
\hline Timber & 29.9 & Not available & 17.9 & Not Available \\
\hline Firewood & 42.4 & 1.74 & 33.9 & 0.4 \\
\hline $\begin{array}{l}\text { Bamboo, bamboo } \\
\text { shoots }\end{array}$ & 4.3 & 3.16 & 1.8 & Not Available \\
\hline No income & 22.4 & 0 & 46.4 & Not Available \\
\hline
\end{tabular}

Source: Analysis from household's survey

When comparing before and after the PFES period, more people in intervention sites perceived that their livelihood and income improved after PFES was instituted compared with the control sites (Table 12). These interviewed households claimed that PFES created additional income for local people.

Table 12. Local perceptions on improving livelihood and income before and after PFES.

\begin{tabular}{cccccc}
\hline & \multicolumn{2}{c}{ Intervention sites } & \multicolumn{2}{c}{ Control sites } \\
\hline Thai Hung & Cang Ty & Ban Lun & Ban Phach & An Thai & Ban Trong \\
\hline $53.3 \%$ & $23.5 \%$ & $33.3 \%$ & $38.3 \%$ & $3.3 \%$ & $26.9 \%$ \\
\hline
\end{tabular}

Source: Analysis from household's survey

Table 13. Average income of households and contribution of PFES in overall income from studied villages (2017)

\begin{tabular}{lccc}
\hline Village & $\begin{array}{c}\text { Average income } \\
\text { (VND/household/year) }\end{array}$ & $\begin{array}{c}\text { Average income from PFES } \\
\text { (VND/household/year) }\end{array}$ & $\begin{array}{c}\text { The ratio of income from PFES to } \\
\text { total income (\%) }\end{array}$ \\
\hline Intervention sites & & 778,270 & $5 \%$ \\
\hline Bản Căng Ty. & $16,000,000$ & $1,091,587$ & $8 \%$ \\
\hline Bản Phách & $13,000,000$ & 735,438 & $2 \%$ \\
\hline Bản Lùn & $30,000,000$ & 509,436 & $1 \%$ \\
\hline Bản Thái & $35,000,000$ & & \\
Hưng & & - & $0 \%$ \\
\hline Control sites & & - & $0 \%$ \\
\hline Bản An Thái & $28,000,000$ & & \\
\hline Bản Trọng & $20,000,000$ & & \\
\hline
\end{tabular}

Source: People's Committee of Moc Chau District (2018), People's Committee of Dong Sang (2018), People's Committee of Muong Sang (2018), People's Committee of Chieng Khua (2018)

According to annual reports published by the Moc Chau District People's committee (2018); Chieng Khua Commune People's Committee (2018); Muong Sang Commune People's committee (2018); and Dong Sang Commune People's committee (2018), annual income generated from PFES payments ranged from VND 402,156/household (USD 17/household) to VND 2,276,661/households (USD 98/household) (Table 7). Average household income in the two control sites (An Thái và Bản Trọng villagers) are higher than the four intervention sites (Thai Hung, Ban Lun, Cang Ty, Ban Phach) 
(Table 7). According to interviews with provincial and commune government agencies, the average income in both control and intervention sites has not changed much before and after PFES, although there is no available published data on annual household incomes. Income from PFES contributes 1 - $8 \%$ of total income for people at intervention sites (Table 13) .

Income from PFES depends on forest areas that each household claims, and most of the time these consist of relatively small areas, amounting to less than 1 ha (see Figure 11). As a result, payments for households is very limited.

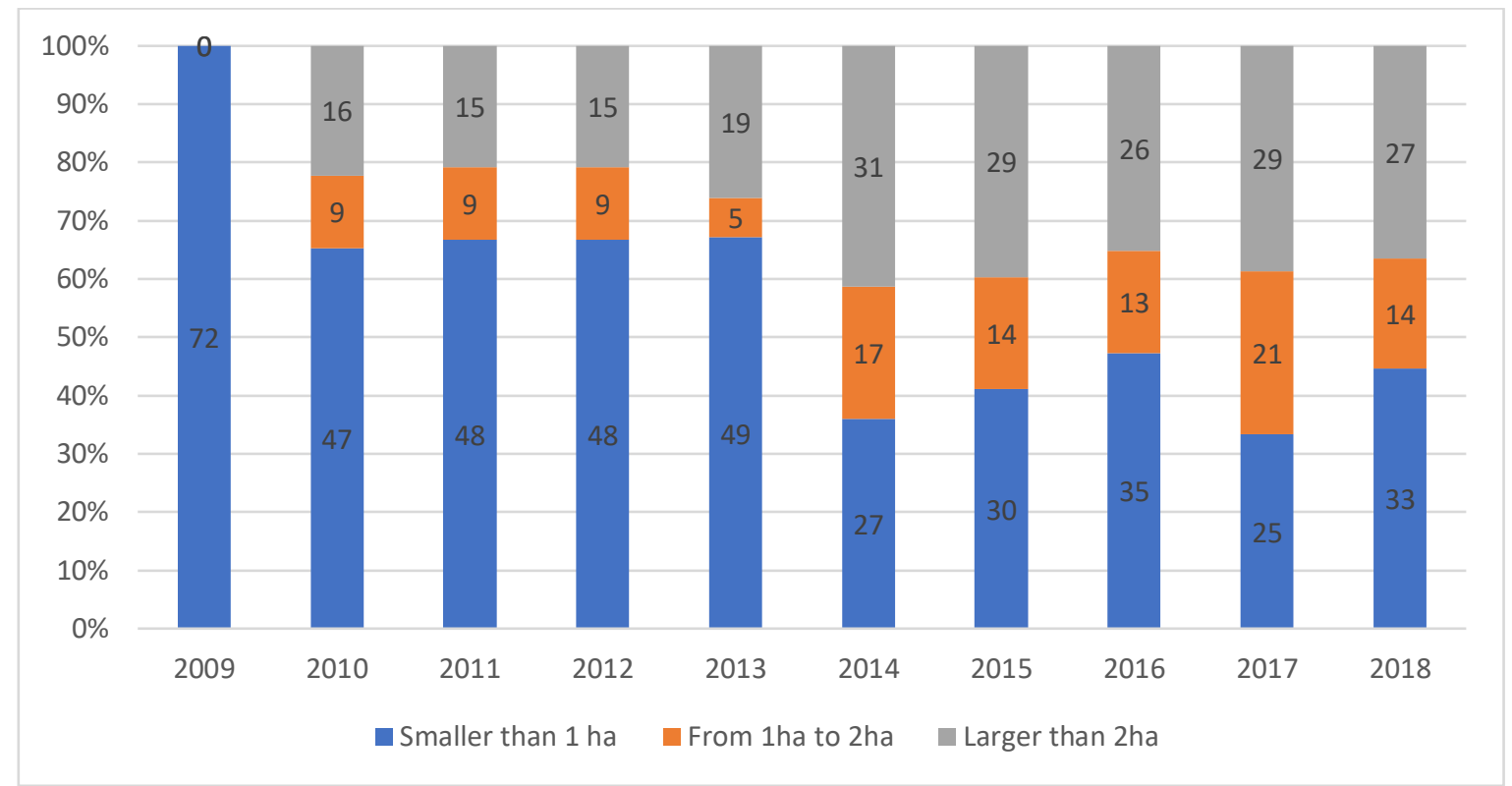

Figure 11. PFES area managed by households interviewed in 4 intervention villages. Source: Forest Protection and Development Fund 2018

\subsubsection{Continuity and stability of payments}

During the focus group discussions, respondents indicated that although payment and contributions of PFES is small, if payments are regular and continuous, the amounts provide an important source of income for local people and can serve as a strong incentive for communities to take part in PFES. Nevertheless, while at the community level PFES payments for community forests are regular and continuous between the 2009-2018 period, PFES payments to individual households were uneven. Specifically, 56 out of 73 (76.7\%) households received interrupted PFES payment between 2009 - 2018. Most of these households received PFES payments for a few years and then did not receive anything from PFES for a couple of years thereafter. According to officers interviewed from the Forest Protection and Development Fund, this is because of poor protection mechanisms or direct violations from households, resulting in the Fund making a decision not to pay them. At intervention sites, in Thai Hung and Na Un villages, $83 \%$ of the interviewed households claimed that despite receiving PFES, their forest areas decreased, which they attributed to flooding and landslides, and as a result, villagers needed to clear forests to expand agriculture areas. Most households interviewed also claimed that the PFES payments are too low. A villager shared that:

We received about 2 million VND/year but if we convert forest to corn production, we can earn at least 60-70 million per year.

Most households receiving PFES for individual forests received an increasing or fluctuating amount of PFES payment over time, as presented in Table 14. 
Table 14. Changes in PFES payments to households between 2009 - 2018 in four intervention sites

\begin{tabular}{|c|c|c|c|c|c|}
\hline & Total & $\mathrm{Na}$ Lun & Thai Hung & Phach & Cang Ty \\
\hline $\begin{array}{l}\text { Total number of individual } \mathrm{HH} \\
\text { receiving PFES }\end{array}$ & 73 & 23 & 13 & 33 & 4 \\
\hline $\begin{array}{l}\text { Number of HHs only receiving PFES } \\
\text { payments for } 1 \text { year in 2018, } \\
\text { therefore cannot be compared }\end{array}$ & 9 & 4 & 2 & 1 & 2 \\
\hline $\begin{array}{l}\text { Number of HHs receiving increased } \\
\text { PFES payments over time }\end{array}$ & 28 & 12 & 8 & 7 & 1 \\
\hline $\begin{array}{l}\text { Number of HHs receiving decreased } \\
\text { PFES payments over time }\end{array}$ & 1 & 0 & 1 & 0 & 0 \\
\hline $\begin{array}{l}\text { Number of HHs that received } \\
\text { fluctuating payment over time }\end{array}$ & 35 & 7 & 2 & 25 & 0 \\
\hline
\end{tabular}

Only $8.2 \%$ of total households received PFES payments for two continuous years and only $1.4 \%$ of total households received PFES payments for five years of continuous PFES payments showing very low additionality of PFES in providing stable income for villagers. This also shows that forest areas that are maintained or expanded over a long period is very limited at our study sites (Table 15).

Table 15. Continuity of PFES payments

\begin{tabular}{|c|c|c|c|c|c|}
\hline & \multirow{2}{*}{$\begin{array}{c}\text { Total } \\
\text { number of } \\
\text { households }\end{array}$} & \multicolumn{4}{|c|}{ Villages } \\
\hline & & Na Lun & $\begin{array}{l}\text { Thái } \\
\text { Hưng }\end{array}$ & Phách & Căng Ty \\
\hline $\begin{array}{l}\text { Total number of individual } \mathrm{HH} \\
\text { receiving PFES }\end{array}$ & 73 & 23 & 13 & 33 & 4 \\
\hline $\begin{array}{l}\text { Interruption }-\mathrm{HH} \text { receiving PFES } 1 \text { or } 2 \\
\text { years, no payments in years } 3-4 \text {, and } \\
\text { then later receiving PFES payments } \\
\text { again }\end{array}$ & 56 & 17 & 10 & 27 & 2 \\
\hline $\begin{array}{l}\text { Number of } \mathrm{HH} \text { only receiving PFES for } \\
1 \text { year }\end{array}$ & 9 & 4 & 3 & 1 & 2 \\
\hline $\begin{array}{l}\text { Number of } \mathrm{HH} \text { receiving PFES } \\
\text { continuously for } 2 \text { years }\end{array}$ & 6 & 2 & 0 & 4 & 0 \\
\hline $\begin{array}{l}\text { Number of } \mathrm{HH} \text { receiving PFES } \\
\text { continuously for more than } 5 \text { years }\end{array}$ & 1 & 0 & 0 & 1 & 0 \\
\hline
\end{tabular}

Source: Authors analysis based on Forest Protection and Development Fund 2018

\subsubsection{Contribution of PFES to community funds and household income for forest protection}

Of the total interviewed households in the four intervention villages, the number of households receiving PFES continuously since 2009 accounted for only a small number (20\% in Thai Hung village; $23.3 \%$ in Na Lun village, $45 \%$ in Phach village and 3.3\% in Cang Ty village). This thus suggests that PFES revenue is only a stable source of income for a small number of households. 
Figure 12 shows that while PFES payments to individual households are small, PFES payments to communities and groups of households are higher in some villages such as Ban Lun, Ban Khua and Thai Hung.

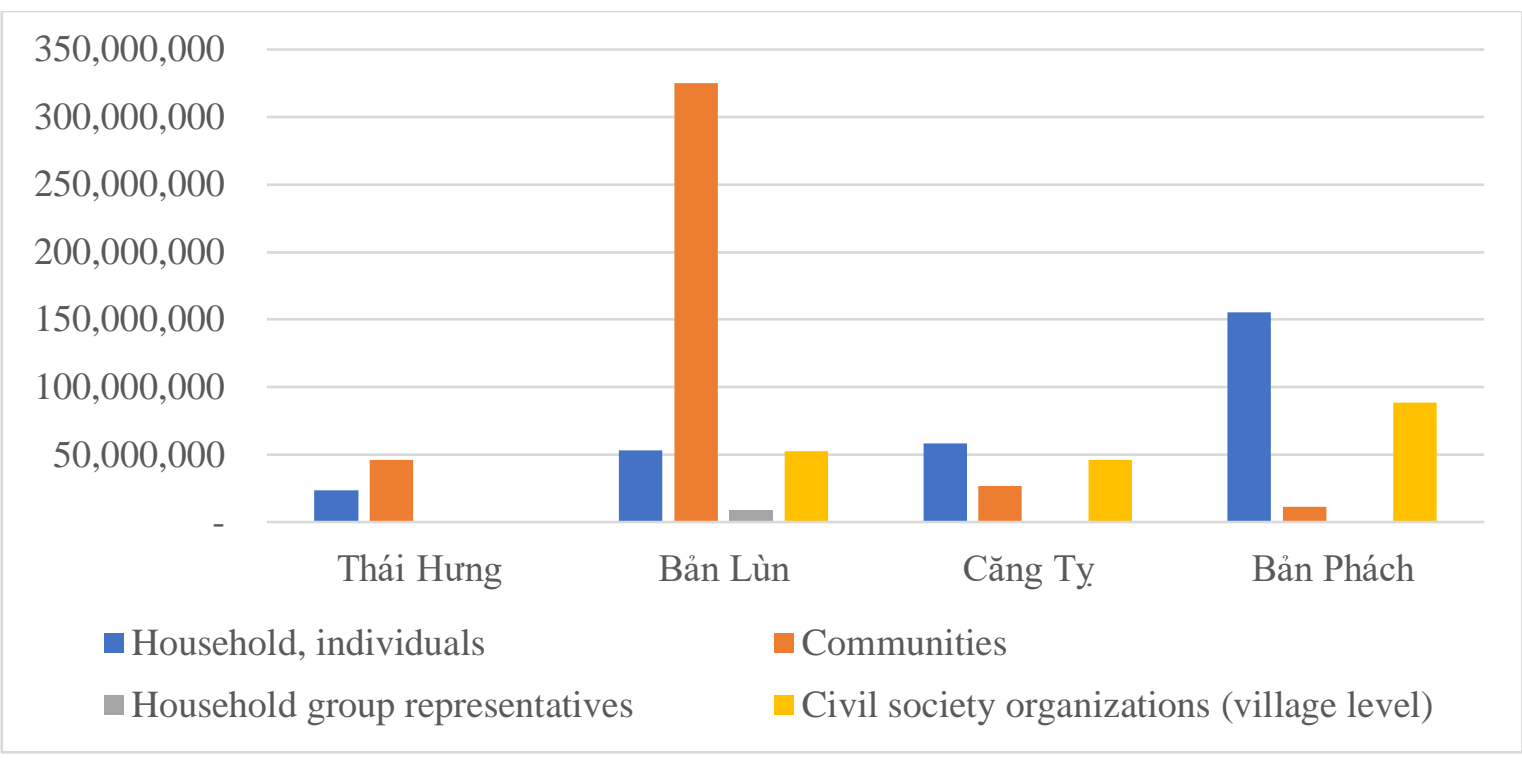

Figure 12. Amount paid to different PFES recipients in surveyed villages in 2017. Source: Son La Forest Protection and Development Fund (2018)

Moreover, while individual households experienced interrupted payments from PFES program, Figure 13 shows that PFES payments to communities are continuous and tend to increase over time in most cases.

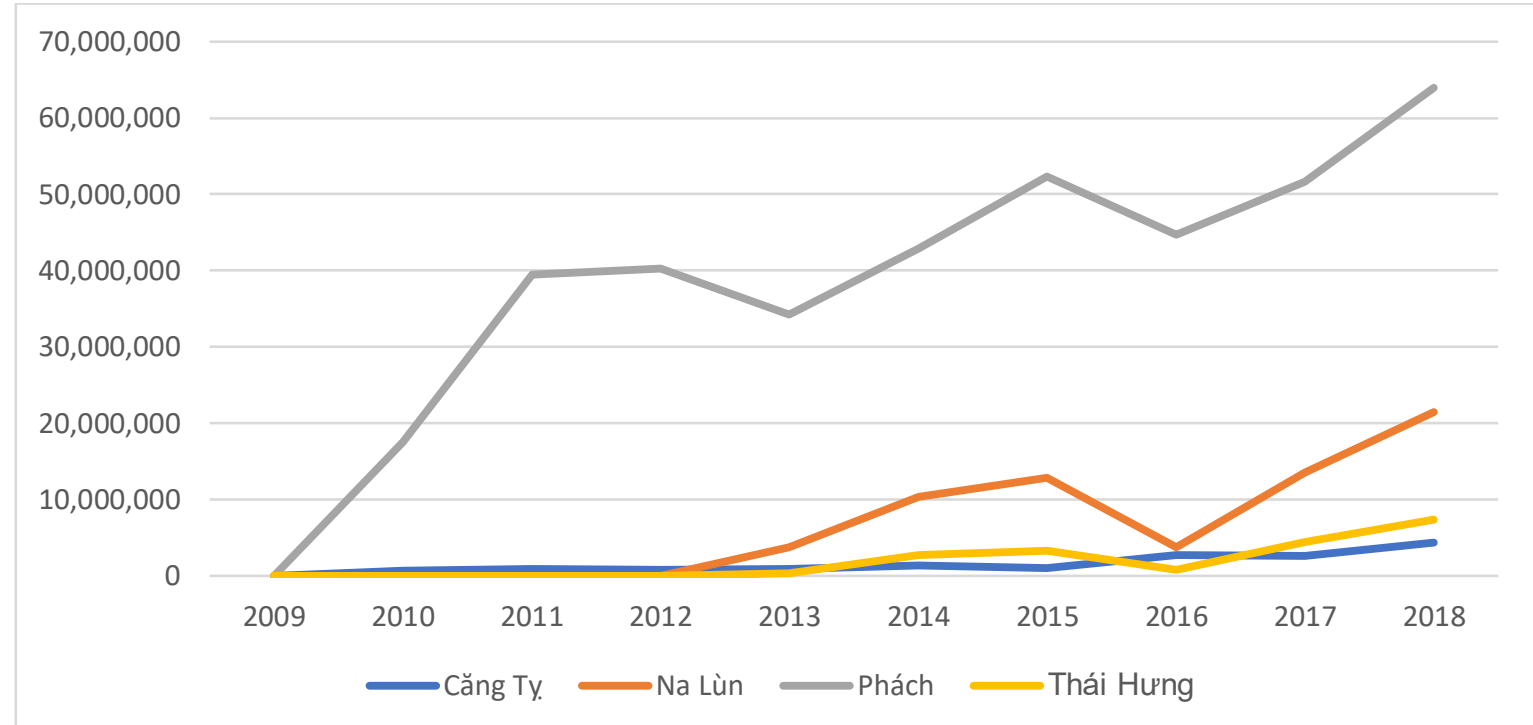

Figure 13. PFES payment to communities in four intervention sites

\subsection{Social impacts}

PFES social impacts are assessed by the Government of Vietnam based on the number of individual households and communities paid under the PFES program, the number of households (particularly the poor) that receive benefits from PFES, and the engagement in forest conservation schemes linked to PFES. Figure 14 shows that the number of forest owners (mostly communities 
and groups of households) receiving PFES funds has increased over the years. From $2013-2015$, the entire province used PFES money to build over 2,689 projects with a total investment of over 57,970 billion VND.

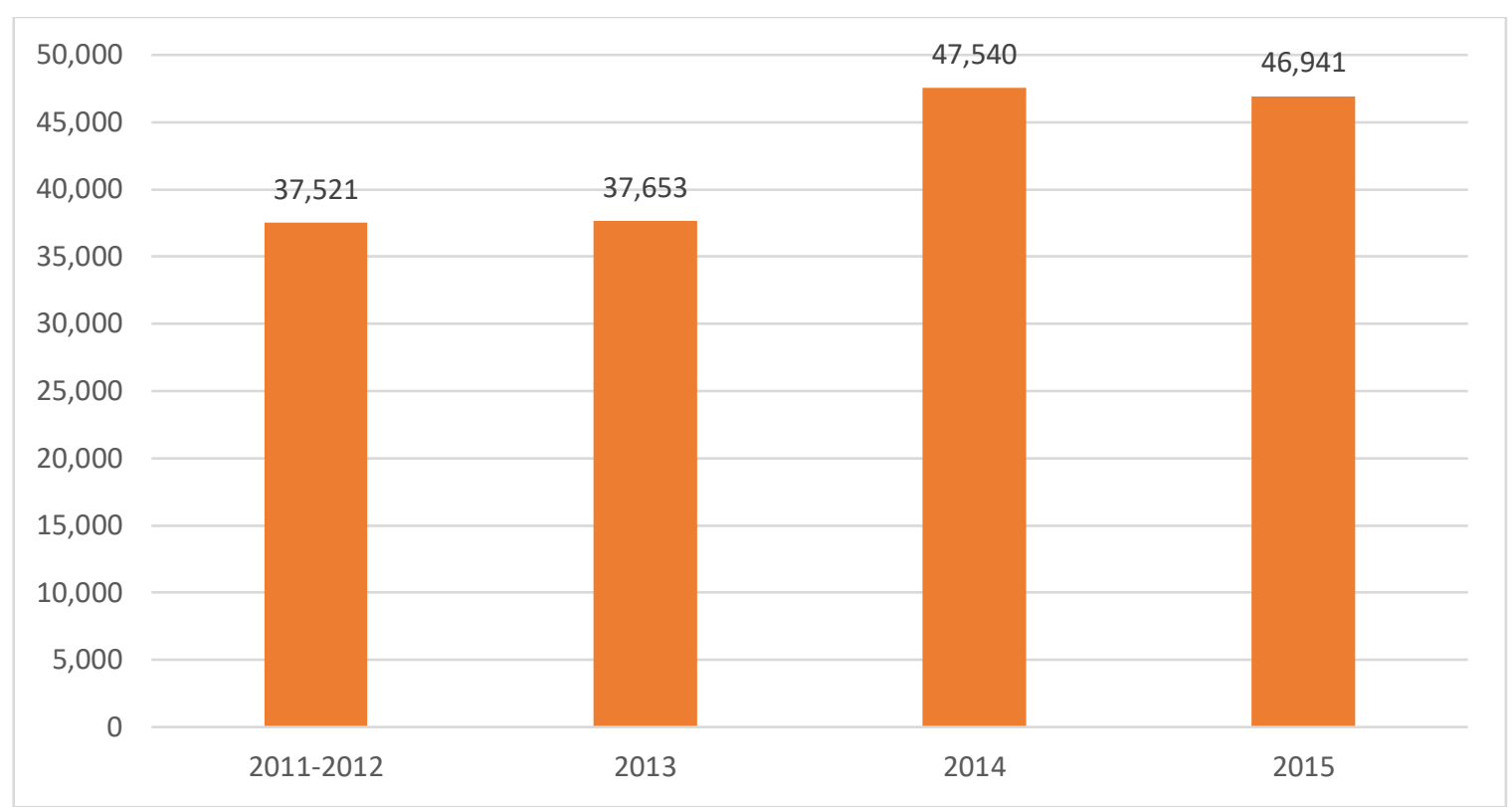

Figure 14. The number of PFES forest owners. Source: Son La FPDF 2017

Table 16. Number of poor households with income from PFES in the studied villages between 2009 - 2017

\begin{tabular}{lllll}
\hline Village & $\begin{array}{l}\text { Total number of } \\
\text { HH }\end{array}$ & $\begin{array}{l}\text { Total number } \\
\text { of poor HH }\end{array}$ & $\begin{array}{l}\text { Number of HH } \\
\text { with income from } \\
\text { PFES }\end{array}$ & $\begin{array}{l}\text { Number of poor } \\
\text { HH with income } \\
\text { from PFES }\end{array}$
\end{tabular}

\begin{tabular}{lcccc}
\hline Intervention sites & & & & \\
\hline Bản Căng Ty. & 86 & 59 & 121 & 59 \\
\hline Bản Phách & 131 & 42 & 64 & 42 \\
\hline Bản Lùn & 130 & 9 & 39 & 0 \\
\hline Bản Thái Hưng & 100 & 0 & & 0 \\
\hline Control sites & & & 0 & 0 \\
\hline Bản An Thái & 80 & 0 & 0 & \\
\hline Bản Trọng & 26 & 7 & $2018)$
\end{tabular}

Source: People's Committee of Dong Sang (2018), People's Committee of Muong Sang (2018), People's Committee of Chieng Khua (2018)

Our findings also show some impacts of PFES on poverty reduction. Interviewed officials from provincial government agencies claimed that before PFES was implemented, budget limitations meant that less than $10 \%$ of poor households could be included in conservation programs as the provincial government would prioritize the households with good educational backgrounds and those that had the labor force to implement the program, which is a more difficult proposition for poorer households to gain access to the program. However, according to the data reported by the People's Committees of 3 communes - Chieng Khua, Muong Sang and Dong Sang, PFES implementation since 2017 indicated that 191 out of 198 poor households in these three communes 
received income from PFES. According to commune data, in all studied villages, $100 \%$ of the poor in the village are eligible to receive payments from PFES (Table 16). The only village without any poor people receiving PFES (Thai Hung) is because there are no poor households listed in that village. Focus group discussions in all four intervention villages show that while PFES can only contribute to 1-5\% of the income among higher- and medium-income households, payments can also contribute up to $12 \%$ of poor household income.

In terms of engagement in forest conservation programs, the number of households participating in forest protection in the form of community forest management is relatively unchanged before and after PFES in both intervention and control villages. Because all villages set up forest management and protection groups to patrol and protect the forest, villagers are compelled to take part regardless of whether they have PFES funding or not. PFES plays little additionality in this regard (Table 17).

At our study sites, there are other existing government programs such as poverty reduction programs and the 30A program, which supports local people in mountainous regions and also pays local people for forest protection efforts. This creates difficulty in assigning attribution and proving the additionality of PFES.

\subsection{Political dilemmas of numbers}

Throughout the research engagement we began to realize the importance of the politics of numbers in data collection, presentation, and analysis. We therefore began to inquire into aspects related to PFES by asking who collects data and how data is collected, analyzing connections to the interest being served by a particular approach to engaging with the data.

National and provincial data on PFES are collected quarterly and annually, and this is only conducted by government agencies. There are three different government agencies that collect data and report on PFES impacts in Son La, including the Son La Forest Protection and Development Fund, the Son La Statistics Department, and the Son La Forest Protection Department (Figure 3). However, these agencies only have expertise and mandates to collect data on forest status, violation cases, PFES payments, and payment distribution. Data on socio-economic indicators and impact of PFES, such as the contribution of PFES to household incomes, has not been collected by government agencies since PFES began in 2009.

Furthermore, these three government agencies collect data using different approaches and reporting timelines, leading to inconsistent data on PFES impact. For example, the Son La Forest Protection and Development Fund needs to report on forests in December, while the Son La Forest Protection and Department reports forest area data in February, and the Son La Statistics Department publishes data on forest area in June. This difference in reporting timelines results in different conclusions about PFES impact. For example, a provincial government interviewee shared that:

The Forest Protection Department has a very limited budget for monitoring and evaluation, so most figures on forest areas are based on previous year statistics and modified by forest protection officers with their own predictions. Recently the province has received technical support on remote sensing and spatial analysis but the data between 2009 - 2017 are poorly collected and analyzed by the Forest Protection Department. In contrast, the Son La Forest Protection and Development Fund has assigned staff, and instituted more secure and regular funding support to conduct ground truthing to verify forest areas in the field. This will lead to more accurate and reliable figures on forest areas.

Another provincial agency interviewed added:

The Son La Statistics Department collects data on forest cover and socio-economic conditions through two sources: reports from the Forest Protection Department and other provincial agencies, complemented by their own survey during every quarter. These data 
sources are then combined and verified first by the Provincial People's Committee to determine whether the data reflect provincial commitments and meet political targets. If the data do not reflect provincial targets and goals, they will be revised.

As a result, although data on PFES is produced in different ways by different government agencies, how the data is selected, analyzed, and presented depends on provincial political goals that these data need to serve. A provincial interviewee further elaborated as follows:

Although we know that data provided by the Son La Forest Protection and Development Fund is more accurate, government authorities cannot use them as official data. According to our existing institutions, the Son La Forest Protection Department is the only authorized agency to collect and inform data on forest cover for the central government. Nevertheless, the final word should come from the Provincial Statistics Department because these figures need to reflect political objectives of the provincial leaders. We might collect and submit data to the Provincial Statistics Department, but how the data is finally chosen and published is not within our authority.

At a smaller governing scale, a district government respondent shared their data reporting dilemmas in the following ways:

What can we do when the party wants us to show that forest cover has to increase over time and still requires us to increase agricultural production activities by expanding agricultural land? We are standing in the crossroads and are very worried that we are under high risk of going to jail. We cannot make payments based on the wrong data on forest areas because if central inspectors find out, we will be punished. However, as provincial governments need to show evidence of positive changes in forest cover, provincial leaders asked us to only report increased forest cover over time.

Another government officer further described the political context of agricultural development pressures relative to PFES by stating:

We all know that Son La is the largest corn producer in Vietnam but in statistical records, we are only ranked as the 2nd or 3rd largest corn producers. This is because corn production comes at the cost of forests, but nobody wants to acknowledge this fundamental fact because we also want to highlight our achievements in forest protection.

\section{Discussion}

The effectiveness of PFES depends on its additionality, namely how the situation would be different in its absence (Bottazzi et al., 2018; Vedel et al., 2015). Implementing a PFES program without monitoring and proving its additionality would reduce the scheme's efficiency and stakeholder confidence in the effectiveness of PFES (Bennett, 2010; Karsenty et al., 2017). Globally, effectiveness of PFES schemes is difficult to assess due to the lack of data, leading to divergent results (Pagiola et al., 2013). Our findings mirror similar findings from research globally, as the lack of available data on forest cover and household income before and after PFES makes it is difficult to fully confirm PFES additionality. There is no available baseline data on PFES implementation in Vietnam in general, nor in Son La in particular, which further undermines the accuracy and rigor of PFES impact assessments.

Furthermore, even when data is available, politics can influence data collection approaches, processes, and outcomes (Rose, 1991; Alonso and Starr, 1987). As we have also shown, data can be designed to meet actors' defined political objectives (Eichelberger, 2012), and official statistics can function as an outcome of sociopolitical processes (Desrosières, 2010; Rosa da Conceição et al., 2018). The fact that the published official data is further filtered by political leaders in Son La sheds additional accuracy challenges in determining the reliability of results on PFES impact as it reflects a 
particular government agenda in demonstrating the increase in forest cover over time. As a result, where data might affect political promotion and result in sanctions of certain government actors related to PFES, data is carefully manufactured and presented to protect their interests. This finding is similar to other programmatic target reporting processes as uncovered in the case of reporting on swidden areas by Pham et al., (2018), which also showed that Son La government authorities do not select and report data on swidden as it implies the government did not do a good job in eliminating deforestation. Strengthening technical capacity and funding for rigorous data collection is therefore insufficient to ensure PFES transparency and deliver evidence-based analysis on PFES impact because it requires concurrently addressing the underlying politics of how data is collected, manufactured, and reproduced.

The fact that government agencies are both PFES implementers and responsible agencies to report on performance of PFES and consists of the only source of data also reveals weak accountability and transparency in PFES. There is therefore a need to have independent monitoring and evaluation systems with the participation of various actors involved in the PFES schemes, such as environmental services providers, environmental services users, and multiple government agencies that perform checks and balances that support data verification to enhance data accountability and transparency. As PFES has environmental and socioeconomic objectives, data on PFES should not be collected solely by PFES agencies but must also integrate existing national monitoring and evaluation systems in the government to establish and monitor the adequate criteria and evaluation of socioeconomic factors. Information on agents of deforestation and forest degradation can also be a powerful tool for civil society to hold agencies to account for their actions (De Sy et al., 2018). Open source of information such as the Hansen data incorporated into monitoring systems as we have done in this study can also provide an independent assessment on PFES impact, especially to account for reductions in annual forest loss. Indeed, our findings show clearly that PFES has not been able to reverse the annual forest loss at the provincial, district and commune levels in Son La. Our study sites highlight that payments are not based on baselines, but rather paid on the basis of an activity being implemented. However, the fact remains that people still receive higher payments despite their failure in protecting existing forests, and more importantly, creates no incentives and conditionality for local people to continue to protect forests.

The current PFES monitoring system only focuses on reporting on forest cover and there is no attempt to compile and make data available on forest quality. Vietnam has yet to introduce any requirements or protocols for environmental monitoring of forest quality, soil erosion or water regulations, even though PFES targets improvements across these environmental services. Focusing on increasing forest cover also means that no incentives are built into the scheme for forest managers to enhance forest quality. The government of Vietnam selected forest cover as the proxy for environmental services in the PFES scheme because it is easy for them to collect these data. However, this approach makes it difficult to identify clear links between actions and the environmental services provided (e.g., whether improving forest cover leads to improved water quality). Even when PFES does result in the improved conservation of forests, that additional forested area may not yield additional environmental services because ecosystem function is not the same as the provision of environmental services, even though the scientific literature and the general public often equate them (Sills et al., 2006). It therefore remains unclear, for example, whether an increase in forest cover will cause an increase in the provision of water. Indeed, this might happen, for example, with native forest conservation, or may even decrease with alternative forms of reforestation. Watershed protection is often based on the assumption that reforestation of areas upstream of dams benefit hydrologically by protecting hydroelectric dams from siltation; however, further research is still needed to confirm whether such reforestation is the optimal landuse strategy to yield those corresponding benefits (Wunder et al., 2005).

Our study also shows that determining additionality of PFES in improving social conditions and local livelihoods is challenging because socioeconomic data before PFES is unavailable and data after 
PFES are not regularly or systematically collected by responsible agencies. However, the intermediate impacts of PFES at the village level in the case studies showed that PFES has had little impact on individual households, limited due to the small areas of forests under their control. Although communities have access to increasing PFES revenue, as villagers were already active in protecting community forests as part of local social norms, our study shows that PFES has created little additionality in incentivizing people to take additional actions in community forest protection. Nevertheless, our study does show that the impact of PFES for the poor might be considerable as the program prioritizes all poor households can gain access as PFES beneficiaries. At the current juncture, the government of Vietnam only assesses the impact of PFES based on the number of poor households benefitting and participating in the PFES scheme and how many people have overcome poverty due to PFES. However, the assessment is merely based on income and net impacts determined via single poverty measures, whereas human well-being is complex and multifaceted (McGregor, 2007).

Our findings also show that PFES payments to households in studied sites is rather low and does not serve as a strong enough financial incentive to motivate people to take part in the PFES scheme, particularly when firewood harvesting/bamboo plantations or other production-oriented activities would generate more income than PFES. Importantly however, according to many households interviewed, PFES payment levels might be low, but if they are regular and a continuous source of income, they would still be interested in engaging in PFES. However, the fact that only a small number of households receive continuous PFES payments over time not only reflects the failure of PFES to maintain and increase existing forest areas but also highlights the weaknesses in the permanence of PFES. Moreover, as Pham et al., (2013) pointed out, combining monetary and nonmonetary benefits such as granting forest land use right certificates has been used by Son La government authorities to attract engagement of local people in the PFES scheme.

Finally, although this study adopts a Before - After - Control - Intervention approach to analyze additionality of PFES, this method can only be accurate and carried out at the village level. Nevertheless, the fact that publicly available data at the village level does not exist in Vietnam nor is systematically and regularly collected poses challenges for assessing PFES impact. Projects might collect data on PFES at the village level as our study has done, but there is a lack of systematic national monitoring and evaluation framework to track PFES impact at this level. Diversifying monitoring and evaluation approaches might be coupled with participatory monitoring approaches to engage local communities.

\section{Conclusion}

Overall, the intent of our research is not to throw the baby out with the bathwater on PFES in Vietnam, but rather to point to potential ways to better understand its processes and better evaluate its impacts. Indeed, PFES can provide an additional layer of protection to forests and livelihood support to rural communities that might not have previously been there. In this paper, we have focused on the many facets of assessing impacts of PFES in Vietnam, at once presenting the most detailed longitudinal assessment to date, while also pointing to potential ideas for improving monitoring and evaluation systems going forward.

Our research shows clearly that assessing PFES impact in Vietnam is politically and technically challenging. Environmental impact of PFES in Vietnam is still debatable and depends on scale, unit of measurement, data collection, as well as which data sources were used to evaluate impact. Proving additionality of PFES in intervention sites where there are multiple programs is especially challenging. While assessing environmental impact of PFES poses difficulties, findings also show minor impacts of PFES on improving individual household income, but significant impact on generating funding for community forestry. Vietnam's experience in implementing PFES highlights the need to combine both monetary and non-monetary benefits to incentivize landowners to 
engage in forest protection. As payment levels are rather small in most cases, combining multiple forest protection programs and livelihood improvement programs might create stronger incentives and support for local people to take part in conservation schemes, although this will make demonstrating PFES impact and its additionality more challenging.

Building on national capacities for assessing and tracking PFES impacts that involve the participation of multiple actors can serve to establish more rigorous impact assessments of PFES in the future. The current PFES monitoring and evaluation system that focuses on forest cover is an encouraging starting point, but further efforts are required to improve the tracking and monitoring of PFES impact on forest quality and poverty reduction. Strengthening monitoring and evaluation systems for PFES does not only require adequate funding devoted to monitoring and application of advanced technology, but also understanding and addressing the underlying politics embedded in data collection and reporting processes, which is also essential for determining the accuracy of PFES impact. Addressing these politics will require strong political commitment from within the government of Vietnam but are also contingent upon more active presence and participation of non-state actors to enhance PFES transparency.

Our findings also suggest that the impact of PFES schemes depend upon who assesses it and their political interests in producing the results. Therefore, establishing independent and participatory monitoring and evaluation systems where environmental services providers, environmental users, the public, and civil society can take participate, and enhanced through the support of advanced technologies will also help to ensure better transparency and accountability of PFES.

Competing interests: The authors declare that they have no competing of interests.

\section{Acknowledgments}

This research is part of ClFOR's Global Comparative Study on REDD+ (www.cifor.org/gcs). It was funded by the Norwegian Agency for Development Cooperation (NORAD; grant no. QZA-16/0110 nr 1500551) and the CGIAR Research Program on Forests, Trees and Agroforestry (CRP-FTA) with financial support from the CGIAR Fund Donors. We would like to express our special thanks to Le Ngoc Dung, Le Manh Thang, Dang Thuy Nga, Nong Hong Hanh, Hoang Minh Hieu, Le Trung Kien and Nguyen Duc Hieu for their kind help during data collection process.

\section{References}

Alonso, W. \& Starr P. (1987). The politics of numbers. Russell Sage Foundation.

Angelsen, A. (2017). REDD+ as result-based aid: General lessons and bilateral agreements of Norway. Review of Development Economics, 21(2), 237-264. doi: https://doi.org/10.1111/rode.12271

Bennett, K. (2010). Additionality: The next steps for ecosystem service markets. Duke Environmental Law \& Policy Forum 20, 417-438.

Bos, A. B. (2020). Richting een verbeterde evaluatie van subnationale initiatieven die tropische ontbossing verminderen. Geo-Info, 17(2), 40-41.

Bottazzi, P., Wiik, E., Crespo, D., \& Jones, J. P. (2018). Payment for environmental "self-service": Exploring the links between Farmers' motivation and additionality in a conservation incentive programme in the Bolivian Andes. Ecological Economics 150, 11-23. doi: https://doi.org/10.1016/j.ecolecon.2018.03.032

Brockhaus, M., \& Angelsen, A. (2012). Seeing REDD+ through 4ls: a political economy framework. Analysing REDD+: challenges and choices. Center for International Forestry Research, Bogor, Indonesia, 15-30. 
De Sy, V., Herold, M., Brockhaus, M., Di Gregorio, M., \& Ochieng, R. M. (2018). Information and policy change: Data on drivers can drive change-if used wisely. In Transforming REDD+, 5566. Center for International Forestry Research (CIFOR).

Desrosières, A. (2010). La politique des grands nombres. Historie de la raison statistique. Paris: La Découverte.

Dung Minh. (2018). Planting fruit trees in Chieng Khua village. Translated from Trồng cây ăn quả ở xã Chiềng Khừa. Nhan Dan Online Newspaper. https://nhandan.com.vn/tin-tuc-kinhte/trong-cay-an-qua-o-xa-chieng-khua-318536/.

Duong, N. T. \& de Groot, W. T. (2018). Distributional risk in PFES: Exploring the concept in the Payment for Environmental Forest Services program, Vietnam. Forest Policy and Economics, 92, 22-32. doi: https://doi.org/10.1016/j.forpol.2018.03.008

Duong, N. T. \& de Groot, W. T. (2020). The impact of payment for forest environmental services (PFES) on community-level forest management in Vietnam. Forest Policy and Economics, 113, 102135. doi: https://doi.org/10.1016/j.forpol.2020.102135

Eichelberger, L. (2012). sustainability and the politics of calculation: Technologies of 'safe water,' subject-making, and domination. Journal of Political Ecology, 19(1): 145-161.

Engel, S. (2016). The devil in the detail: a practical guide on designing payments for environmental services. International Review of Environmental and Resource Economics, 9(1-2), 131-177. doi: https://doi.org/10.1561/101.00000076

Gupta, A., Lövbrand, E., Turnhout, E., \& Vijge, M. J. (2012). In pursuit of carbon accountability: the politics of REDD+ measuring, reporting and verification systems. Current Opinion in Environmental Sustainability, 4(6), 726-731. doi: https://doi.org/10.1016/j.cosust.2012.10.004

Gupta, A., Vijge, M. J., Turnhout, E., \& Pistorius, T. (2014). Making REDD+ transparent: the politics of measuring, reporting and verification systems. In Transparency in global environmental governance: critical perspectives (pp. 181-20).

Hansen, M. C., P. V. Potapov, R. Moore, M. Hancher, S. A. Turubanova, A. Tyukavina, D. Thau, S. V. Stehman, S. J. Goetz, T. R. Loveland, A. Kommareddy, A. Egorov, L. Chini, C. O. Justice, and J. R. G. Townshend. (2016). "High-Resolution Global Maps of 21st-Century Forest Cover Change." Science 342 (15 November): 850-53. Data available on-line from: http://earthenginepartners.appspot.com/science-2013-global-forest.

Hasan, S. S., Zhang, Y., Chu, X., \& Teng, Y. (2019). The role of big data in China's sustainable forest management. Forestry Economics Review.

Jebiwott, A. (2016). Forest cover change and ecosystem services of Katimok forest reserve, Baringo County, Kenya (Doctoral dissertation). Kenya: Egerton University.

Karsenty, A., Aubert, S., Brimont, L., Dutilly, C., Desbureaux, S., Ezzine de Blas, D., \& Le Velly, G. (2017). The economic and legal sides of additionality in payments for environmental services. Environmental Policy and Governance, 27(5), 422-435. doi: https://doi.org/10.1002/eet.1770

Le Velly, G., \& Dutilly, C. (2016). Evaluating payments for environmental services: Methodological challenges. PLOS One, 11(2), e0149374. doi: https://doi.org/10.1371/journal.pone.0149374

Mcgregor, Ja. (2007). Researching human well-being: from concepts to methodology. In Gough I \& Mcgregor J (Eds), Well-being in developing countries: new approaches and research strategies (pp. 316-350). Cambridge University Press.

Mohebalian, P. M., \& Aguilar, F. X. (2016). Additionality and design of forest conservation programs: Insights from Ecuador's Socio Bosque Program. Forest Policy and Economics, 71, 103-114. doi: https://doi.org/10.1016/j.forpol.2015.08.002

Mùi Sơn \& Minh Hải. (2019). Moc Chau - Son La: Lam forest blatantly destroyed Chieng Khua forest. Translated from Mộc Châu - Sơn La: Lâm tặc ngang nhiên tàn phá rừng Chiềng Khừa. Kien 
Thuc Online Newspaper. https://kienthuc.net.vn/xa-hoi/moc-chau-son-la-lam-tac-ngangnhien-tan-pha-rung-chieng-khua-1209627.html.

Naeem, S., Ingram, J. C., Varga, A., Agardy, T., Barten, P., Bennett, G., Bloomgarden, E., Bremer, L.L., Burkill, P., Cattau, M., Ching, C., Colby †, M., Cook, D.C., Costanza, R., DeClerck, F., Freund, C., Gartner, T., Goldman-Benner, R., Gunderson, J., Jarrett, D., Kinzig, A.P, Kiss, A., Koontz, A., Kumar, P., Lasky, J.R., Masozera, M., Meyers, D., Milano, F., Naughton-Treves, L., Nichols, E., Olander, L., Olmsted, P., Perge, E., Perrings, C., Polasky, S., Potent, J., Prager, C., Quétier, F., Redford, K., Satersont, K., Thoumi, G., Vargas, M.T., Vickerman, S., Weisser, W., Wilkie, D., Wunder, S. (2015). Get the science right when paying for nature's services. Science, 347(6227), 1206-1207. doi: https://doi.org/10.1126/science.aaa1403

Pagiola, S., Carrascosa von Glehn, H., \& Taffarello, D. (2013). Brazil's experience with payments for environmental services. São Paulo: SMA/CBRN, 274.

People's Committee of Chieng Khua Commune. (2018). Reports on socioeconomic context in Chieng Khua Commune. Retrieved from People's Committee of Chieng Khua Commune.

People's Committee of Dong Sang Commune. (2018). Reports on socioeconomic context in Dong Sang Commune. Retrieved from People's Committee of Dong Sang Commune.

People's Committee of Moc Chau District. (2018). Reports on socioeconomic context in Moc Chau District. Retrieved from People's Committee of Moc Chau District.

People's Committee of Muong Sang Commune. (2018). Reports on socioeconomic context in Muong Sang Commune. Retrieved from People's Committee of Muong Sang Commune.

Pham, T.T., Bennett, K., Vu, T. P., Brunner, J., Le Ngoc, D., \& Nguyen, D. T. (2013). Payments for forest environmental services in Vietnam: from policy to practice. CIFOR Occasional Paper, (93).

Pham, T.T., Loft, L., Bennett, K., Phuong, V. T., \& Brunner, J. (2015). Monitoring and evaluation of Payment for Forest Environmental Services in Vietnam: From myth to reality. Ecosystem services, 16, 220-229. doi: https://doi.org/10.1016/j.ecoser.2015.10.016

Pham, T.T., Moeliono, M., Wong, G. Y., \& Brockhaus, M. (2018). The politics of swidden: A case study from Nghe An and Son La in Vietnam. Land Use Policy. Rosa da Conceição, H., Börner, J., \& Wunder, S. (2018). REDD+ as a public policy dilemma: understanding conflict and cooperation in the design of conservation incentives. Forests, 9(11), 725. doi: https://doi.org/10.1016/j.landusepol.2017.10.057

Phạm, T.T., Đào, T.L.C., Hoàng, T.L., Nguyễn, Đ.T., Lê, M.T., Nông, H.H. và Đặng, T.N. 2018. Tác động của chi trả dịch vụ môi trường rừng (PFES) tại Sơn La, Việt Nam. Nghiên cứu chuyên đề 188. Bogor, Indonesia: CIFOR.

Rose, N. (1991). Governing by Numbers: Figuring Out Democracy. Accounting, Organizations and Society, 16(7): 673-692.

Sills E, Wendland KJ, Pattanayak SK, Cassingham K and Alger K. 2006. Watershed protection by forests: Vital ecosystem service or smoke and mirrors? Presentation, 3rd Chilean Congress of Forest Sciences, Concepcion, Chile

Son Ha. (2019). Moc Chau (Son La): Illegal loggers raging, forest rangers powerless? Kinh Te Nong Thon Online Newspaper https://kinhtenongthon.vn/moc-chau-son-la-lam-tac-hoanh-hanhkiem-lam-bat-luc-post26594.html.

Son La Forest Protection and Development Fund. (2018). 10 years report on PFES implementation in Son La. Son La Forest Protection and Development Fund, Son La, Vietnam.

Son La Forest Protection Department (2018). Reports on annual forest change for 2018. Retrieved from Son La Forest Protection Department.

Son La Forest Protection Department (2019). Forest cover dataset. http://www.kiemlam.org.vn/Desktop.aspx/List/So-lieu-dien-bien-rung-hangnam/NAM_2019/.

Son La Statistic Department. (2016). Annual report on Son La Development. Son La, Vietnam. 
Son La Statistics Department. (2018). Statistical Yearbook of Son La. Retrieved from Son La Statistics Department.

Sunderlin, W. D., Larson, A. M., Duchelle, A. E., Sills, E. O., Luttrell, C., Jagger, P., ... \& Aryani, R. (2016). Technical guidelines for research on REDD+ subnational initiatives. CIFOR.

Trædal, L. T., \& Vedeld, P. O. (2017). Livelihoods and land uses in environmental policy approaches: The case of PFES and REDD+ in the Lam dong province of Vietnam. Forests, $8(2), 39$. doi: https://doi.org/10.3390/f8020039

Tran, T. T. H., Zeller, M., \& Suhardiman, D. (2016). Payments for ecosystem services in Hoa Binh province, Vietnam: An institutional analysis. Ecosystem Services, 22, 83-93. doi: https://doi.org/10.1016/j.ecoser.2016.10.001

Vedel, S. E., Jacobsen, J. B., \& Thorsen, B. J. (2015). Forest owners' willingness to accept contracts for ecosystem service provision is sensitive to additionality. Ecological Economics, 113, 15-24. doi: https://doi.org/10.1016/j.ecolecon.2015.02.014

Vietnam Administration of Forestry. (2013). News bulletin November 8, 2013. http://tongcuclamnghiep.gov.vn/LamNghiep/Index/diem-tin-ngay-08112013-1410.

Wang, B., Niu, X., \& Wei, W. (2020). National Forest Ecosystem Inventory System of China: Methodology and Applications. Forests, 11(7), 732. doi: https://doi.org/10.3390/f11070732

Wichelns, D., Milan, F., Hoanh, C. T., \& Phuong, N. D. (2016). Household opportunity costs of protecting and developing forest lands in Son La and Hoa Binh Provinces, Vietnam. International Journal of the Commons, 10(2), 902-928. doi: http://doi.org/10.18352/ijc.620

Wunder, S, Ibarra, E and Bui, D.T. 2005. Payment is Good but Control is Better: Why Payments for Forest Environmental Services in Vietnam Have so far Remained Incipient. Bogor, Indonesia: Center for International Forestry Research

Wunder, S. 2005. Payments for environmental services: Some nuts and bolts. CIFOR occasional paper 42. Bogor, Indonesia: Center for International Forestry Research.

Wunder, S. (2007). The efficiency of payments for environmental services in tropical conservation. Conservation Biology, 21(1), 48-58. doi: https://doi.org/10.1111/j.15231739.2006.00559.x 